Preprint: Escrig-Olmedo, E., Rivera-Lirio, J. M., Muñoz-Torres, M. J., \& Fernández-Izquierdo, M. Á. (2017). Integrating multiple ESG investors' preferences into sustainable investment: A fuzzy multicriteria methodological approach. Journal of Cleaner Production, 162, 1334-1345.

\title{
Integrating multiple ESG investors' preferences into sustainable investment: A \\ fuzzy multicriteria methodological approach
}

\begin{abstract}
The integration of environmental, social and governance (ESG) criteria into the evaluation process of assets is a theme that is widely accepted among socially responsible investors. In this process, however, the integration of investors' preferences has not been adequately developed. The challenge is to integrate the preferences of heterogeneous investors-not only conventional investors but also investors who are particularly sensitive to sustainability issues (socially responsible investors)— considering that socially responsible investors are not necessarily homogeneous. This paper attempts to address this challenge by developing a methodological approach based on an application of fuzzy multicriteria decision-making methods (MCDM) to integrate ESG investors' preferences, as jointly considered. Because investors' preferences may vary depending on which material aspects are considered within a sector, this study has been tested using clothing-sector data. Results confirm the usefulness of the methodological approach proposed for a proper generation of a 'commercial solution' that integrates the preferences of various investors and simultaneously is consistent with individually defined preferences.
\end{abstract}

Keywords: Sustainable investment; Socially responsible (SR) investor; environmental, social and governance (ESG) criteria; institutional investor; Fuzzy multicriteria decision-making method (MCDM); clothing-sector data. 
Preprint: Escrig-Olmedo, E., Rivera-Lirio, J. M., Muñoz-Torres, M. J., \& Fernández-Izquierdo, M. Á. (2017). Integrating multiple ESG investors' preferences into sustainable investment: A fuzzy multicriteria methodological approach. Journal of Cleaner Production, 162, 1334-1345.

\section{Introduction}

This study proposes a methodological tool for assessing the sustainable production and management of companies with the aim of improving the integration of multiple environmental, social, and corporate governance (ESG) investor preferences that must act together. This tool could be translated for use in the financial markets in the case of institutional investors' decision-making process.

Sustainable investment is considered a comprehensive term for what is known as responsible investment, socially responsible investment (SRI), or ESG investment (Utz et al., 2015). Following authors such as Busch et al. (2016), this paper is based on the term 'sustainable investment' as a general term to define an investment process that has a potential positive impact on sustainable development through the integration of not only financial concerns but also long-term ESG criteria into investment decisions. On this basis, in this study socially responsible investors (SR investors) are defined as those which adopt a long term investment horizon (Guyatt, 2005), expecting returns no lower than other investors; although, some are willing to sacrifice returns for corporate sustainability (Statman et al., 2008).

According to Eurosif (2014), the key driver of the sustainable-investment market remains institutional investor demand. Pension funds form a subset of institutional investors with a long-term perspective (Neubaum and Zahra, 2006). In this setting, the investment strategies developed by institutional investors in general and pension funds in particular become especially relevant.

ESG integration is becoming mainstream not only in business but also in asset managers and owners' operations (Orsato et al., 2015). ESG integration is 'the explicit inclusion 
Preprint: Escrig-Olmedo, E., Rivera-Lirio, J. M., Muñoz-Torres, M. J., \& Fernández-Izquierdo, M. Á. (2017). Integrating multiple ESG investors' preferences into sustainable investment: A fuzzy multicriteria methodological approach. Journal of Cleaner Production, 162, 1334-1345.

by asset managers of ESG risks and opportunities into traditional financial analysis and investment decisions based on a systematic process and appropriate research sources' (Eurosif, 2014). It is not possible to ensure but neither it can be denied that ESG factors may offer investors potential long-term performance advantages when they are integrated into investment analysis and decision making (Capelle-Blancard and Mojon, 2012; Dam and Scholtens, 2015; Revelli and Viviani, 2015).

Indeed, according to Eurosif (2014), all forms of integration practices have grown by 65\% between 2011 and 2013, making this one of the fastest-growing investment strategies. However, practitioners have identified difficulties in implementing sustainable investment in pension funds related to the screening process and the development of long-term strategies that could generate value without sacrificing financial return (Sievänen, 2014). As highlighted by Juravle and Lewis (2008), there are three levels of impediments to the development of sustainable investment: institutional, organisational and individual. One of the institutional impediments mentioned by these authors-and noted as critical for the future of mainstream sustainable investmentconcerns conflicts of interest among the stakeholders in investment institutions along the investment value chain. This conflict could represent a hotspot for pension fund management, which has a fiduciary responsibility to heterogeneous stakeholders (multiple beneficiaries with multiple interests); different plan members can have different pre-existing values or sensitivity to ESG concerns (Himick and AudoussetCoulier, 2015). Accordingly, as the authors show, the variety of individual preferences makes it difficult to incorporate ESG criteria into the investment-selection process. Consequently, the challenge is to integrate the preferences of heterogeneous investorsnot only those who are particularly sensitive to sustainability issues (SR investors) but 
Preprint: Escrig-Olmedo, E., Rivera-Lirio, J. M., Muñoz-Torres, M. J., \& Fernández-Izquierdo, M. Á. (2017). Integrating multiple ESG investors' preferences into sustainable investment: A fuzzy multicriteria methodological approach. Journal of Cleaner Production, 162, 1334-1345.

also other investors (i.e., non-SR investors) — considering that the various typologies of investors are not necessarily homogeneous.

This paper attempts to overcome the above-referenced challenge by developing a methodological approach based on an application of fuzzy multicriteria decisionmaking methods (MCDM). The output obtained after applying the proposed methods will be an accurate input for an investment decision-making process-e.g. for a pension fund — that integrates various plan members' interests without forcing a consensus.

This methodological approach is designed in two steps. In the first step, ESG company criteria are assessed and evaluated at the production and management levels. In the second step, investors' preferences are integrated to design a unique investment decision solution. In this second step, two potential scenarios have been designed to represent some of the heterogeneity of investors that exist in the market.

Because investors' sentiments might vary depending on which material aspects are considered within a given sector and for the sole purpose of illustrating the proposed method, this study has used data from the clothing sector, which provides a valuable example of significant environmental and social impacts along the supply chain. Moreover, the clothing sector is one of the most global industries in the world.

The methodological approach proposed in this paper can contribute to the development of sustainable investment in two important ways:

(i) As Hurson and Zopounidis (1995) state, the first phase in the portfolio management process consists in the consideration of investor's preferences. The proposed methodological approach concerns this phase by extending the analysis through the existence of more than one 
Preprint: Escrig-Olmedo, E., Rivera-Lirio, J. M., Muñoz-Torres, M. J., \& Fernández-Izquierdo, M. Á. (2017). Integrating multiple ESG investors' preferences into sustainable investment: A fuzzy multicriteria methodological approach. Journal of Cleaner Production, 162, 1334-1345.

investor. Therefore the integration of different investors' preferences could provide a more accurate input for the analysis of the companies that constitutes the investment universe of a portfolio. It allows institutional investors and fund managers to build various portfolios that could be more easily accepted by an increasing number of investors.

(ii) Second, this approach could help organizations not only to manage their resources depending on what kind of investors they wish to attract but also to further their engagement with their stakeholders.

This methodological approach could be extended to any other financial decision-making process that could be characterised by a lack of previous consensus among various market actors.

The remainder of this paper is organized as follows. After this introduction, there is a brief analysis of the theoretical background of this research. Later, the paper presents an analysis of the main distinguishing features of the methods applied and explains the design of the study. After the presentation of the results obtained, the article finishes by providing the main conclusions.

\section{Sustainable institutional investment and integration of investors' preferences}

Sustainable investment market has grown substantially over time (Eurosif, 2014; US SIF, 2014), and with it, studies on the implications of investing responsibly have increased (Humphrey et al., 2015). According to Eurosif (2014), the key driver of the market remains institutional investor demand. Large investors undertake most SRI, whereas retail investors comprise a small fraction of total SRI and are usually involved 
Preprint: Escrig-Olmedo, E., Rivera-Lirio, J. M., Muñoz-Torres, M. J., \& Fernández-Izquierdo, M. Á. (2017). Integrating multiple ESG investors' preferences into sustainable investment: A fuzzy multicriteria methodological approach. Journal of Cleaner Production, 162, 1334-1345.

through participation in SRI funds (Eurosif 2010). The vast majority of responsible investment occurs via institutional investors (Eurosif, 2014).

The market for sustainable investment has undergone a qualitative change as sustainable investments become more diverse over time (Scholtens, 2014). Current strategies include negative screening/positive screening within funds, ESG integration, engagement and voting, 'best-in-class', and sustainability-themed and investing impact (Eurosif, 2014; US-SIF, 2014). As Trinks and Scholtens (2015) state, despite the gradual maturity of sustainable investment, the original practice of negative screening is a frequent strategy (Eurosif 2014). However, it must be emphasized that ESG strategies vary considerably across countries; for example, in France the negative screening has little relevance (Capelle-Blancard and Mojon 2014) because market is traditionally defined by combining the Best-in-Class and Sustainability themed strategies (Eurosif, 2014). In this context, as Duuren et al. (2015) highlight, 'both professional and retail investors prefer to consider ESG in more holistic terms rather than using exclusions'. Accordingly, SR investors can search for firms that engage in balanced management of ESG criteria based on their overall profile, instead of applying an exclusionary policy (Berry and Junkus, 2013). Consequently, ESG integration is becoming one of the most common strategies in the field of responsible investment (Scholtens, 2014). However, ESG integration is not without difficulties.

Several studies have focused on the research about the main features of conventional investors and SR investors (Renneboog et al., 2008). Nevertheless, not all SR investors share the same goals, and thus, various types of investors can coexist (Derwall, 2011). 
Preprint: Escrig-Olmedo, E., Rivera-Lirio, J. M., Muñoz-Torres, M. J., \& Fernández-Izquierdo, M. Á. (2017). Integrating multiple ESG investors' preferences into sustainable investment: A fuzzy multicriteria methodological approach. Journal of Cleaner Production, 162, 1334-1345.

Consequently, it is not possible to consider all SR investors as a homogeneous group.

Table 1 shows the most representative studies of segments of SR investors.

\section{\{Table 1: Studies about segments of SR-investors\}}

The literature is still attempting to explain the determinants of an individual's investment style (e.g., Kumar, 2009). Cronqvist et al. (2015) suggest that an investor's style is a matter of biological predisposition that translates into preferences for value or growth stocks, along with environmental factors that determine an individual's portfolio tilt with respect to value and growth. Other studies argue that investors' values and personal beliefs are increasingly reflected in their investment decisions (Trinks and Scholtens, 2015). Indeed, as authors such as Adam and Shauki (2014) highlight, investors' behaviour regarding sustainable investment is influenced by financial, social, ethical and environmental goals.

Sustainable rating agencies and sustainable indices are the primary referents in terms of corporate sustainability assessment for the sustainable investment market (Duuren et al, 2015). However, investment proposals do not explicitly consider the differences mentioned above, nor do they integrate the investment preferences of a variety of investors. Accordingly, it is necessary to research the development of alternative screening approaches that consider inclusionary factors (Berry and Junkus, 2013) and to accept the challenge of integrating the preferences of investors with different sensitivities with respect to sustainability issues that require collective action. 
Preprint: Escrig-Olmedo, E., Rivera-Lirio, J. M., Muñoz-Torres, M. J., \& Fernández-Izquierdo, M. Á. (2017). Integrating multiple ESG investors' preferences into sustainable investment: A fuzzy multicriteria methodological approach. Journal of Cleaner Production, 162, 1334-1345.

\section{Method}

This section presents a step-by-step procedure that outlines a methodological approach to the sustainable assessment and integration of ESG criteria into the investment process using fuzzy MCDM. Multicriteria methodologies have been widely used to assess environmental, social, and governance performance because of their multidimensional character as a solution to the problems experienced by decision makers when confronting this complex concept (Krajnc and Glavic, 2005; Prato, 2003; Boggia and Cortina, 2010; Erol et al., 2011; Escrig et al., 2015). However, the literature contains few studies in the field of fuzzy MCDM that address the incorporation of investors' preferences for a more accurate process of portfolio selection. Authors such as Tiryaki and Ahlatcioglu (2005) propose a new fuzzy ranking and weighting algorithm and apply their algorithm to the Istanbul Stock Exchange. Sevastjanov and Dymova (2009) suggest a new method for stock ranking based both on the MCDM and on optimization. Finally, Bilbao-Terol et al. (2012) develop a fuzzy MCDM to construct portfolios for investors who consider ethical, social, and environmental criteria when making investment decisions.

This paper presents an application of fuzzy MCDM, specifically fuzzy TOPSIS (Technique for Order Preference by Similarity to Ideal Situation), which is suitable for assessing ESG performance because it enables the measurement of a multidimensional concept such as ESG using both qualitative and quantitative criteria while considering expert knowledge.

Expert knowledge is a key source of information for the design of an evaluation framework that can be integrated in various ways (Vveinhart and Gulbovaitè, 2015). 
Preprint: Escrig-Olmedo, E., Rivera-Lirio, J. M., Muñoz-Torres, M. J., \& Fernández-Izquierdo, M. Á. (2017). Integrating multiple ESG investors' preferences into sustainable investment: A fuzzy multicriteria methodological approach. Journal of Cleaner Production, 162, 1334-1345.

Fuzzy TOPSIS does not require an agreed and consistent expertise because the system finds the optimal answer to the positive ideal solution among the various preferences that are taken into account, rendering explicit the possible existence of different perceptions of the same problem.

Figure 1 is a schematic representation of this method.

\section{\{Figure 1. Integration of ESG criteria and investors' preferences. An outline\}}

Both data and indicators have been collected from the Thomson Reuters ASSET4 database for 2013. Thomson Reuters ASSET4 is a worldwide leading database of ESG information. This database has been used in previous studies-e.g., by Schäfer et al. (2006), Ortas et al. (2015), Miras-Rodríguez et al., (2015) and Ferrero-Ferrero et al. (2016) — to examine issues related to sustainability. Nonetheless, the use of ASSET4 has the sole objective of testing with empirical data the methodological approach.

The Thomson Reuters ASSET4 Database organises the indicators into 18 categories within four main areas:

(i) Social performance: employment quality (SOEQ), safety and health (SOHS), training and development (SOTD), diversity and opportunity (SODO), human rights (SOHR), community (SOCO), and product responsibility (SOPR).

(ii) Environmental performance: emissions reduction (ENER), resource reduction (ENRR), and product innovation (ENPI).

(iii) Economic performance: client loyalty (ECCL), performance (ECPE), and shareholder loyalty (ECSL). 
Preprint: Escrig-Olmedo, E., Rivera-Lirio, J. M., Muñoz-Torres, M. J., \& Fernández-Izquierdo, M. Á. (2017). Integrating multiple ESG investors' preferences into sustainable investment: A fuzzy multicriteria methodological approach. Journal of Cleaner Production, 162, 1334-1345.

(iv) Corporate governance performance: board structure (CGBS), compensation policy (CGCP), shareholder rights (CGSR), vision and strategy (CGVS), and board functions (CGBF).

ESG scores reveal the quality of a firm's business practices and they highlight those companies that look beyond short-term returns to emphasise long-term value (Kranjac et al., 2012). This issue has been taken up by Thomson Reuters ASSET4. The score of ASSET4 categories shows how firms have implemented and could implement socially responsible strategies aimed at maximizing profits in the long-term. It is possible to find categories focus on company's management commitments and capacities, and measures that are related to effectiveness and long term growth. For example, the economic performance dimension measures a company's capacity to generate sustainable growth and a high return on investment through the efficient use of all its financial and nonfinancial resources what might have been considered as 'the reflection of a company's overall financial health and its ability to generate long-term profits' (Ferrero-Ferrero et al., 2016).

The categories and areas from Thomson Reuters ASSET4 range from 0 to 100 and represent equally weighted calculations for relative company performance. This study uses clothing-sector data for testing the methodological approach. The clothing sector provides a valuable example of significant environmental and social impacts along the supply chain; moreover, it is one of the world's most global industries. The final sample is composed of 52 listed companies.

Escrig et al. (2015) methodological approach combines two MCDM methods. Specifically, it is designed in two steps. In the first step, the production and 
Preprint: Escrig-Olmedo, E., Rivera-Lirio, J. M., Muñoz-Torres, M. J., \& Fernández-Izquierdo, M. Á. (2017). Integrating multiple ESG investors' preferences into sustainable investment: A fuzzy multicriteria methodological approach. Journal of Cleaner Production, 162, 1334-1345.

management of each company are assessed according to the company's ESG performance. In the second step, the investor's preferences related to ESG and financial domains are integrated to design a unique investment decision solution.

Step 1. Assessment of ESG performance. The first step in the methodology was related to the elaboration of synthetic indicators for each corporate sustainability domaincorporate environmental, social, governance and financial performance. The Thomson Reuters ASSET4 database provides synthetic indicators for each domain mentioned above. However, as an equally weighted rating, these indicators have several limitations such as the offsetting of scores between domains (Escrig et al., 2014). Consequently, this paper's methodological approach includes unique synthetic ESG and financial indicators, using Thomson Reuters ASSET4 data as the inputs of a fuzzy inference system (FIS), which uses fuzzy set theory to map inputs (features in fuzzy classification) to outputs (classes of fuzzy classification). FIS is an appropriate methodology for assessing ESG performance because it is capable of representing complex concepts that are difficult to quantify. FIS methodology has been previously applied to assess sustainability (Andriantiatsaholiniaina et al. 2004; Muñoz et al. 2008; Rivera et al., 2010, Phillis et al., 2011; among others). In this case, four Mamdani-type fuzzy inference systems were designed for each area (social, environmental, economic, and corporate governance), following the sequence below (Jang, 1993):

Step 1.1. Fuzzification: fuzzy inputs are represented by membership functions that translate crisp values into fuzzy inputs. Through a fuzzification process, the crisp (nonfuzzy) numbers become grades of membership for each linguistic term of fuzzy sets, because every membership function associates a grade with each linguistic term. The 
Preprint: Escrig-Olmedo, E., Rivera-Lirio, J. M., Muñoz-Torres, M. J., \& Fernández-Izquierdo, M. Á. (2017). Integrating multiple ESG investors' preferences into sustainable investment: A fuzzy multicriteria methodological approach. Journal of Cleaner Production, 162, 1334-1345.

literature defines many membership functions, such as the triangular function, the trapezoidal function, and the Gaussian function. The choice of membership function is based on subjective decision criteria and relies heavily on time-consuming trial and error because the choice of membership function is not deterministic and has no unique solution (Tahera et al., 2008). In this study, following Phillis and Daves (2009), the defined membership functions for the input and output variables are triangular membership functions.

$$
\mu_{A}(x)=\left\{\begin{array}{ll}
0 & \text { if } x \leq a \\
\frac{x-a}{b-a} & \text { if } a \leq x \leq b \\
\frac{c-x}{c-b} & \text { if } b \leq x \leq c \\
0 & \text { if } x \geq c
\end{array}\right\}
$$

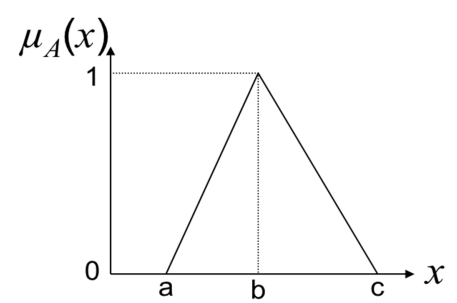

$a, b$ and $c$ represent the $x$ coordinates of the three vertices of $\mu \mathrm{A}(\mathrm{x})$ in a fuzzy set $\mathrm{A}$ (a: lower boundary, c: upper boundary where membership degree is zero, and b: the centre where membership degree is 1$)$.

Step 1.2. Fuzzy rules base: fuzzy 'if-then' (also called 'antecedent-consequence') rules are generated from the concept of the dominant rule of a data sample (Carrera and Mayorga, 2008). The if-then rules represent knowledge and describe the logical evolution of the system according to linguistic values (Phillis and Andriantiatsaholiniaina, 2001). Rules are defined on the basis of expert knowledge.

Step 1.3. Decision-making unit or inference engine: application of the rules to the fuzzy inputs. As an example, environmental performance can be evaluated as a function of emissions reduction (ENER), resource reduction (ENRR) and product innovation 
Preprint: Escrig-Olmedo, E., Rivera-Lirio, J. M., Muñoz-Torres, M. J., \& Fernández-Izquierdo, M. Á. (2017). Integrating multiple ESG investors' preferences into sustainable investment: A fuzzy multicriteria methodological approach. Journal of Cleaner Production, 162, 1334-1345.

(ENPI) in a manner that disallows the offset of results between different indicators. These variables are expressed in crisp numbers and are translated into fuzzy numbers through previously defined membership functions. The fuzzy output-top environmental performance, high environmental performance, medium environmental performance, low environmental performance, and poor environmental performancewill be generated as a consequence of the designed fuzzy rules. One rule could be 'IF ENER is high THEN environmental performance is high'. The design of the rules reflects the expert knowledge. At the same time, if there are different rules, it will be necessary to add up the corresponding resulting fuzzy sets into a single output.

Step 1.4. Defuzzification: using a defuzzification process, the fuzzy output is translated into numerical values. The literature describes several defuzzification methods (Lee, 1990). For this research, we have chosen the centroid method, which is the most frequently used (Wu and Lee, 2007). The nearer the result is to unity, the better the 'ESG performance'. The fuzzy-logic toolbox MATLAB was used to enter the membership functions and fuzzy rules.

Step 2. The integration of investors' preferences. In this step, the investor's preferences related to ESG and financial domains are integrated to design a unique investment decision solution using fuzzy TOPSIS MCDM.

The paper proposes two potential scenarios due to the huge heterogeneity of investors that exist in the market, and in order to operationalize the integration of the different kind of investors' profiles. To test the applicability of the proposed methodological approach for the join management of different investors' preferences, both scenarios have been designed considering the different types of investors according to the 
Preprint: Escrig-Olmedo, E., Rivera-Lirio, J. M., Muñoz-Torres, M. J., \& Fernández-Izquierdo, M. Á. (2017). Integrating multiple ESG investors' preferences into sustainable investment: A fuzzy multicriteria methodological approach. Journal of Cleaner Production, 162, 1334-1345.

aforementioned literature (Nilsson, 2009; Praestbro and Winther, 2011; Derwall et al., 2011; Ballestero et al., 2012) not only the SR investors but also conventional ones.

Scenario 1: This scenario represents three types of investors, one is a conventional investor and the other two are SR investors:

(i) Investor $1.1\left(\mathrm{DM}_{1.1}\right)$. Conventional investor: an investor who invests with the primary goal of maximizing financial returns. Financial aspects are very important to this kind of investor; environmental and social concerns are less important. In addition, corporate governance concerns are high important because according to Guyatt (2005), institutional investors are more favourable towards integrating corporate governance concerns into their investment process than they are towards integrating environmental and social criteria.

(ii) Investor $1.2\left(\mathrm{DM}_{1 \cdot 2}\right)$. Strong Socially Responsible Investor: this investor invests based on his or her social and personal values. As Renneboog et al. (2008) highlight, if investors invest in SRI funds or in companies with high standards of corporate sustainability, then they worry less about financial returns than do conventional investors. Consequently, this typology of investor perceives ESG aspects as very important in the decision-making process of investment. Financial criteria are important.

(iii) Investor $1.3\left(\mathrm{DM}_{1.3}\right)$. Instrumental Socially Responsible Investor: an investor who prioritises good financial performance without neglecting ESG aspects. Therefore, this investor considers financial aspects as very important in the investment process and ESG criteria as important. 
Preprint: Escrig-Olmedo, E., Rivera-Lirio, J. M., Muñoz-Torres, M. J., \& Fernández-Izquierdo, M. Á. (2017). Integrating multiple ESG investors' preferences into sustainable investment: A fuzzy multicriteria methodological approach. Journal of Cleaner Production, 162, 1334-1345.

Scenario 2: The three investors represented in this scenario are SR investors, with differences in the way they approach to sustainability. Socially responsible investors expect returns no lower than other investors; however, some are willing to sacrifice returns for social responsibility (Statman et al., 2008). Specifically, the defined investors' profiles are:

(i) Investor $2.1\left(\mathrm{DM}_{2.1}\right)$. Environmentally conscious investor (green investor): an investor who mainly focuses on environment-friendly performance, even if financial returns are less than in other securities. Investment strategies such as "engagement" allow investors to actively influence the activity of controversial businesses. That is the reason why a green investor would be willing to invest in polluting sectors/industries (such as clothing sector).

(ii) Investor $2.2\left(\mathrm{DM}_{2 \cdot 2}\right)$. Environmental \& Governance investor: this investor considers governance and environmental domains very important in his investment decision. That is consistent with Walls et al. (2012), who state that governance and environmental aspects show many significant associations.

(iii) Investor $2.3\left(\mathrm{DM}_{2 \cdot 3}\right)$. Pro-social investor: investor who wants to invest in sustainable securities in accordance with the Triple Bottom Line, even if returns are less than in other securities.

The integration of ESG criteria into the investment process has been developed considering the following criteria: financial-economical aspects $\left(\mathrm{F}=\mathrm{C}_{1}\right)$, environmental aspects $\left(E=C_{2}\right)$, social aspects $\left(S=C_{3}\right)$, and governance aspects $\left(G=C_{4}\right)$. All of the variables $\left(\mathrm{C}_{1}, \mathrm{C}_{2}, \mathrm{C}_{3}\right.$ and $\left.\mathrm{C}_{4}\right)$ are called positive, i.e., they must be maximized. 
Preprint: Escrig-Olmedo, E., Rivera-Lirio, J. M., Muñoz-Torres, M. J., \& Fernández-Izquierdo, M. Á. (2017). Integrating multiple ESG investors' preferences into sustainable investment: A fuzzy multicriteria methodological approach. Journal of Cleaner Production, 162, 1334-1345.

Step 2.1: Determine the weighting of evaluation criteria. The linguistic variables are used by the decision makers, DMs $(\mathrm{s}=1, \ldots, \mathrm{k})$, to assess the weights of the criteria and the ratings of the alternatives, which are expressed in positive triangular fuzzy numbers as shown in Tables 2 and 3. Triangular fuzzy numbers are the most common in the literature (Wang and Elhag, 2006; Yang and Hung, 2007).

\{Table 2: Linguistic variables for the relative importance weights of four criteria\}

\{Table 3: Linguistic variables for the ratings\}

The weight given to every aspect and to the rating of companies in each of the domains portrays a simulation of the investors' behaviour. Thus, the validity of the model as a method for incorporating the preferences of every investor in the investment process is tested.

Investors weight the ESG and financial domains to reflect the importance that they attribute to each aspect according to their preferences. Tables 4 and 5 show the assessment information provided by the three simulated decision-makers for each scenario, where aggregated fuzzy numbers are obtained by averaging the fuzzy opinions of investors. That is, $v_{j}=\left(v_{j}^{1}+v_{j}^{2}+v_{j}^{3}\right) / 3$ and $x_{i j}=\left(x_{i j}^{1}+x_{i j}^{2}+x_{i j}^{3}\right) / 3$, where $v_{j}$ and $x_{i j}$ are the weights of the relative importance and ratings given by the investors. For example, in the scenario 1 , the domain $\mathrm{F}$ is of very high importance for a conventional investor and an instrumental SR-investor and of high importance for a strong SR-investor. In addition, the results that company $A_{1}$ has obtained in the domain $F$ signal poorly for the three investors. 
Preprint: Escrig-Olmedo, E., Rivera-Lirio, J. M., Muñoz-Torres, M. J., \& Fernández-Izquierdo, M. Á. (2017). Integrating multiple ESG investors' preferences into sustainable investment: A fuzzy multicriteria methodological approach. Journal of Cleaner Production, 162, 1334-1345.

\{Table 4: The relative importance weights of the four criteria by 3 DMs per scenario\}

\{Table 5: Ratings of the first four companies with respect in the four criteria by 3

\section{DMs per scenario\}}

Step 2.2: Establishment and normalization of a decision matrix $\tilde{D} \quad$ where the number of criteria is $n$ and the number of alternatives is $m$. A fuzzy decision matrix will be obtained with $m$ rows and $n$ columns. In this case, however, the fuzzy decision matrix involves the same dimension and does not need normalization: every criterion/attribute $-C_{1}, \ldots, C_{n}-$ has been assessed using the same set of fuzzy linguistic variables (Wang and Elhag, 2006).

\{Table 6: The fuzzy normalized decision matrix and fuzzy weights of four alternatives per scenario\}

Step 2.3: Calculate the weighted, normalized fuzzy decision matrix shown in Table 7. The weighted, normalized value $\tilde{v}_{i j}$ is calculated by multiplying the weights $\tilde{w}_{j}$ of criteria with the normalized fuzzy decision matrix $\tilde{r}_{i j}$.The weighted, normalized decision matrix $\tilde{R}$ for each criterion is calculated through the following relations:

$$
\begin{aligned}
& \tilde{R}=\left[\tilde{v}_{i j}\right]_{m \times n} \quad i=1, \ldots, m, j=1, \ldots, n \\
& \text { Where } \quad \tilde{v}_{i j}=\tilde{r}_{i j}(\cdot) \tilde{w}_{i}
\end{aligned}
$$

\{Table 7: The fuzzy weighted, normalized decision matrix per scenario\}

Step 2.4: Determine the fuzzy positive-ideal solution (FPIS, A+), and the fuzzy negativeideal solution (FNIS, A-). The basic concept of TOPSIS is that the chosen alternative should have the shortest distance from the positive-ideal solution (PIS), i.e., the solution 
Preprint: Escrig-Olmedo, E., Rivera-Lirio, J. M., Muñoz-Torres, M. J., \& Fernández-Izquierdo, M. Á. (2017). Integrating multiple ESG investors' preferences into sustainable investment: A fuzzy multicriteria methodological approach. Journal of Cleaner Production, 162, 1334-1345.

that maximizes the benefit criteria and minimizes the cost criteria. The chosen alternative should also have the farthest distance from the negative-ideal solution (NIS), i.e., the solution that maximizes the cost criteria and minimizes the benefit criteria (Sghafian and Hejazi, 2005).

$$
\begin{aligned}
& A^{+}=\left(\tilde{v}_{1}^{+}, \tilde{v}_{2}^{+}, \ldots, \tilde{v}_{n}^{+}\right)=\left\{\left(\max \tilde{v}_{i j} \mid i=1, \ldots, m\right), j=1, \ldots, n\right\} \\
& A^{-}=\left(\tilde{v}_{1}^{-}, \tilde{v}_{2}^{-}, \ldots, \tilde{v}_{n}^{-}\right)=\left\{\left(\min \tilde{v}_{i j} \mid i=1, \ldots, m\right), j=1, \ldots, n\right\}
\end{aligned}
$$

Here $\tilde{v}_{j}^{+}(1,1,1)$ and $\tilde{v}_{j}^{-}(0,0,0)$

Step 2.5: Calculate distance from the FPIS and FNIS for each alternative. According to Bojadziev and Bojadziev (1995), the distance between two triangular fuzzy numbers $(\tilde{\mathrm{A}})$ and $(\tilde{B})$ is calculated as follows:

$$
d(\tilde{A}, \tilde{B})=\sqrt{\frac{1}{3}}\left[\left(a_{1}-b_{1}\right)^{2}+\left(a_{2}-b_{2}\right)^{2}+\left(a_{3}-b_{3}\right)^{2}\right]
$$

The separation of each alternative from the ideal solution is given as follows:

$$
d_{i}^{+}=\sum_{j=1}^{k} d\left(\tilde{v}_{i j}, \tilde{v}_{j}^{+},\right), i=1, \ldots, m
$$

Similarly, the separation from the negative ideal solution is given as follows:

$$
d_{i}^{-}=\sum_{j=1}^{k} d\left(\tilde{v}_{i j}, \tilde{v}_{j}^{-},\right), i=1, \ldots, m
$$

Step 2.6: Calculate the relative closeness coefficient to the ideal solution shown in Table 8. The alternative with the highest closeness coefficient (CC) value will be the best choice.

$$
C C \quad \text { or } \quad \bar{R}_{i}=\frac{\bar{d}_{i}^{-}}{\bar{d}_{i}^{+}+\bar{d}_{i}^{-}}, i=1, \ldots, m
$$

\{Table 8: The distance measurement per scenario\} 
Preprint: Escrig-Olmedo, E., Rivera-Lirio, J. M., Muñoz-Torres, M. J., \& Fernández-Izquierdo, M. Á. (2017). Integrating multiple ESG investors' preferences into sustainable investment: A fuzzy multicriteria methodological approach. Journal of Cleaner Production, 162, 1334-1345.

Step 2.7: Rank preference order. The ranking of the alternatives can be determined according to the $\mathrm{CC}$ in descending order. The best alternative is the one closest to the FPIS and farthest from the FNIS.

\section{Results and discussion}

This section presents the results obtained after applying the method designed for the clothing-sector data.

Table 9 shows the results derived from the designed fuzzy TOPSIS MCDM compared to the results according to Thomson Reuters ASSET4 for each scenario.

Column I-the integrated solution—shows the ranking provided by the fuzzy TOPSIS considering each company's closeness to the optimal solution based on two premises: i) the optimal solution is that to which the three investors give the maximum value; and ii) the assessment of each ESG and financial domain has been developed without allowing compensation among indicators. Consequently, this ranking reflects the integrated investors' assessment of each company according to all investor's preferences. .

Column II-the non-integrated solution-presents the ASSET4 equal-weighted and non-integrated ranking. These typologies of rankings and ratings are the main reference for the sustainable-investment decision process in the financial market.

\section{\{Table 9: An example of fuzzy TOPSIS MCDM rankings vs. Asset4 rankings per scenario\}}

Although movements between rankings are not dramatic, they could have consequences during the investment process because any movement in rankings could imply the company's exit from the portfolio. For example, in the scenario 1, focusing on the first twenty companies, it can be observed that some companies' positions have been modified because of the correction of unbalances presented in the ESG and/or financial 
Preprint: Escrig-Olmedo, E., Rivera-Lirio, J. M., Muñoz-Torres, M. J., \& Fernández-Izquierdo, M. Á. (2017). Integrating multiple ESG investors' preferences into sustainable investment: A fuzzy multicriteria methodological approach. Journal of Cleaner Production, 162, 1334-1345.

scores according to the preferences expressed by the simulated investors. For example, 'MARKS AND SPENCER' and 'GILDAN ACTIVEWEAR' lost two positions from the ASSET4 ranking to the fuzzy TOPSIS ranking. Although they present very high ESG scores, their financial-economical scores are not as high-notice that financial criteria are important or very important for the three investors. Other example is the case of 'PACIFIC BRANDS', which receives high scores in financial, environmental and corporate governance aspects but lower scores in social criterion. Consequently, this company loses three positions from the ASSET4 ranking to the fuzzy TOPSIS ranking. Social dimension is important or very important for two of the simulated investors. Regarding the movements in the scenario 2, company "GIORDANO INTL" lost seven positions applying this methodological approach because its scores in the environmental and social criteria were LOW, and these are the two most important criteria for the three investors. On the other hand, company "CHRISTIAN DIOR" gained four positions because its scores in the environmental and social criteria were HIGH.

In an equally weighted ranking (Thomson Reuters ASSET4) these unbalances could be hidden, but in a context in which every score is analysed and weighted according to different interests jointly considered (fuzzy TOPSIS), this situation could be detected and corrected, generating changes in a company's position.

The value added of this methodological approach is the possibility of offering an investment solution that integrates different investors' interests without forcing a consensus. If the proposed investment product fits well with the investors' preferences jointly considered without sacrificing individual interests, then the output obtained would be a proper solution. Consequently, this investment product could be accepted by 
Preprint: Escrig-Olmedo, E., Rivera-Lirio, J. M., Muñoz-Torres, M. J., \& Fernández-Izquierdo, M. Á. (2017). Integrating multiple ESG investors' preferences into sustainable investment: A fuzzy multicriteria methodological approach. Journal of Cleaner Production, 162, 1334-1345.

a variety of investors who should act together. This could be the context of pension funds. The following paragraphs analyse the correlation between the solution proposed (fuzzy TOPSIS) and the preferences of each investor individually considered. Moreover, the correlation of these individual preferences with the ranking provided by Thomson Reuters ASSET4 has been studied. As Figure 2 shows, the fuzzy TOPSIS solution is highly and significantly correlated with the ranking that each individual investor would elaborate individually.

\section{\{Figure 2. Correlation among individual investors' rankings vs. fuzzy TOPSIS rankings per scenario\}}

The closeness of all of the data points, in other words the lack of scatter, shows a high degree of correlation.

In the case of the scenario 1, the linear relationship between the correlation's coordinate points on the $\mathrm{Y}$ axis (fuzzy TOPSIS ranking) and the investors' ranking on the $\mathrm{X}$ axis is almost perfect for the three investors (investor $1.1=0.959$; investor $1.2=0.984$ and investor $1.3=0.994)$. Moreover, if we compare the results of this methodological approach with the results of the Thomson Reuters ASSET4 database, our model obtains a better fit to the preferences of different investors, except for investor 2 (investor 1.1= 0.942 ; investor $1.2=0.985$ and investor $1.3=0.986$ ). In this case, the correlation coefficient between investor 1.2 and ASSET4 practically coincide compared to the correlation coefficient between investor 1.2 and fuzzy TOPSIS. It is noteworthy that investor 1.2 has been designed as a 'strong SR investor' who considers ESG aspects as very highly important and economic aspects as highly important in the investment 
Preprint: Escrig-Olmedo, E., Rivera-Lirio, J. M., Muñoz-Torres, M. J., \& Fernández-Izquierdo, M. Á. (2017). Integrating multiple ESG investors' preferences into sustainable investment: A fuzzy multicriteria methodological approach. Journal of Cleaner Production, 162, 1334-1345.

decision-making process. This scenario, in which the weight given by the investor to each aspect is almost the same, could be consistent with an equally weighted rating.

Likewise, in the scenario 2, the linear relationship between fuzzy TOPSIS ranking and the investors' ranking is almost perfect for the three investors (investor 2.1=0.985; investor $2.2=0.993$ and investor $2.3=0.995)$. Moreover, if we compare the results of this methodological approach with the results of Thomson Reuters ASSET4, this model obtains a better fit to the preferences of different investors (Figure 2).

Consequently, using this methodological approach, it has been possible to integrate different investors' financial and ESG preferences into the evaluation of corporate sustainability performance. Moreover, this approach facilitates the integration of ESG criteria into the investment process (i) by considering investors' particular sustainability interests and (ii) without forcing a consensus. These results confirm the validity of the suggested method.

\section{Conclusions}

Sustainable investing is one of the key drivers of corporate sustainability practices (Waring and Edwards, 2008). To place sustainable investment into the mainstream of the financial markets, it is necessary to advance both the demand side, making investors, companies and society as a whole aware regarding the need to collaborate on sustainability concerns (Husted and Sousa-Filho, 2016), and the offer side, providing investment products which can satisfy investors' interests accordingly. This paper is focused on the second question, paying special attention to institutional investors as key drivers of the sustainable investment market. However, even though the approach adopted in this paper highlights the existence of a specific sustainable investment 
Preprint: Escrig-Olmedo, E., Rivera-Lirio, J. M., Muñoz-Torres, M. J., \& Fernández-Izquierdo, M. Á. (2017). Integrating multiple ESG investors' preferences into sustainable investment: A fuzzy multicriteria methodological approach. Journal of Cleaner Production, 162, 1334-1345.

market, it also shows the importance of introducing ESG aspects in traditional investment products in a way that renders ESG preferences compatible with financial preferences.

Currently, it seems that the investor must choose between 'traditional' investments (strictly financially oriented) or sustainable investing (ESG oriented). This scenario presents several limitations. First, the two possibilities are presented as incompatible, that is, as the investor must choose between profitability and sustainability. This presentation is incompatible with the significant amount of literature showing a positive relationship between corporate social and financial performance (Endrikat, 2014) and placing the sense of this relationship into a context of excellence in both production and management. Moreover, this scenario does not take into account that socially responsible investors are not a homogeneous group. The reasons for the investment behaviour of socially responsible investors can vary from strictly personal values to a more instrumental approach. These interests are translated into investment decisions that do not necessarily coincide despite the fact that both types of investors can be classified as SR investors.

Moreover, these limitations could be critical in a context in which different investors must act together, as in the case of pension funds. In these cases, there are two possible solutions: (i) to prefer one investor's demands to those of others; or (ii) to offer a unique and integrative solution that allows managers to satisfy individual investors' demands. This paper is an attempt to overcome this challenge by offering a practical solution for the integration of SR and non-SR investors in a unique investment product. 
Preprint: Escrig-Olmedo, E., Rivera-Lirio, J. M., Muñoz-Torres, M. J., \& Fernández-Izquierdo, M. Á. (2017). Integrating multiple ESG investors' preferences into sustainable investment: A fuzzy multicriteria methodological approach. Journal of Cleaner Production, 162, 1334-1345.

Specifically, this paper develops a methodological approach based on an application of the fuzzy TOPSIS multicriteria decision-making method (MCDM), for assessing the financial and ESG performance of companies considering the preferences of every investor while facilitating the integration of ESG criteria into the investment process.

To illustrate the suggested methodology while avoiding differences in investors' preferences caused by sectoral differences, this methodological approach has been tested using clothing-sector data. The results suggest a strong and positive association between the preferences of various investors and their fuzzy TOPSIS final rankings. Results confirm the usefulness of the solution proposed for a proper ESG and financial integration taking into account various investors' preferences.

This methodological approach helps advance the process of ESG integration in two particulars: (i) it aggregates multidimensional information to avoid the problem of information loss; and (ii) it allows the integration of multiple investors' specific sensibilities and objectives, reaching a consensus about which companies are sustainable and helping translate that consensus into company behaviour.

The result of this study will be specially informative for improving the knowledge of the institutional investors and other market actors.

(i) For institutional investors and fund managers: literature shows a positive relationship between corporate social and financial performance and this relationship is useful, not only for SR investors but also for the 'traditional' ones. In these sense, this sustainable investment solution proposes a practical management tool that is especially relevant for institutional investors in general and for fund managers in particular. Both of these actors can use this tool to integrate financial and ESG information into their investment 
Preprint: Escrig-Olmedo, E., Rivera-Lirio, J. M., Muñoz-Torres, M. J., \& Fernández-Izquierdo, M. Á. (2017). Integrating multiple ESG investors' preferences into sustainable investment: A fuzzy multicriteria methodological approach. Journal of Cleaner Production, 162, 1334-1345.

decisions by considering different investors' preferences in the design of the best portfolio and to further a better engagement with their various stakeholders (companies, rating agencies, plan members, etc.) along the investment value chain. Moreover, this integration could reduce the extra-financial risks.

(ii) For companies' management: the integration of the perspectives of different investors could help companies in two ways. On the one hand, by managing their resources in accordance with the kind of investors they might wish to attract, and on the other hand, by better defining and designing engagement strategies with their stakeholders.

(iii) For financial market: this financial and ESG assessment methodology can offer to the market greater confidence in terms of the adequacy of the investment with respect to the SR and non-SR preferences of every investor, because the assessment supports a good alignment with the concept of sustainability while addressing all of the investors' concerns.

This research has some limitations that may lead to future studies: (i) as in the design of the fuzzy TOPSIS model, the weight given to every aspect and to the rating of companies in each of the domains portrays a simulation of the investors' behaviour; we advise the use of an expert panel or the Delphi method to better fit a real investor's preferences; (ii) the inherent limitations in the selection of a database could condition the use of one set of indicators over others when measuring ESG performance; for example, the indicators used in this paper do not allow us to take into account that firms could implement greenwashing strategies aimed at maximizing profits in the short-term which is not consistent with a long-term corporate sustainability required by SR 
Preprint: Escrig-Olmedo, E., Rivera-Lirio, J. M., Muñoz-Torres, M. J., \& Fernández-Izquierdo, M. Á. (2017). Integrating multiple ESG investors' preferences into sustainable investment: A fuzzy multicriteria methodological approach. Journal of Cleaner Production, 162, 1334-1345.

investors (iii) the consideration of a subset of investors in order to operationalize the empirical research.

\section{Abbreviations}

ESG: environmental, social and governance

FIS: fuzzy inference systems

MCDM: multicriteria decision-making method

SRI: socially responsible investment

SR-investor: socially responsible investor

TOPSIS: Technique for Order Preference by Similarity to Ideal Situation

\section{Acknowledgements}

This paper is supported by European Union's Horizon 2020 Research and Innovation Programme under Grant Agreement No. 693642, project SMART (Sustainable Market Actors for Responsible Trade).

\section{References}

1. Adam, A. A., and Shauki, E. R. (2014). Socially responsible investment in Malaysia: behavioral framework in evaluating investors' decision making process. Journal of Cleaner Production, 80, 224-240. doi:10.1016/j.jclepro.2014.05.075

2. Andriantiatsaholiniaina, L.A., Kouikoglou, V.S., and Phillis, Y.A. (2004). Evaluating strategies for sustainable development: Fuzzy logic reasoning and sensitivity analysis. Ecological Economics, 48(2), 149-172. DOI:10.1016/j.ecolecon.2003.08.009

3. Ballestero, E., Bravo, M., Pérez-Gladish, B., Arenas-Parra, M., and Plà-Santamaria, D. (2012). Socially responsible investment: A multicriteria approach to portfolio 
Preprint: Escrig-Olmedo, E., Rivera-Lirio, J. M., Muñoz-Torres, M. J., \& Fernández-Izquierdo, M. Á. (2017). Integrating multiple ESG investors' preferences into sustainable investment: A fuzzy multicriteria methodological approach. Journal of Cleaner Production, 162, 1334-1345.

selection combining ethical and financial objectives. European Journal of Operational Research, 216(2), 487-494. DOI:10.1016/j.ejor.2011.07.011

4. Berry, T. C., and Junkus, J. C. (2013). Socially responsible investing: An investor perspective. Journal of Business Ethics, 112(4), 707-720. DOI 10.1007/s10551$012-1567-0$

5. Bilbao-Terol, A.; Arenas-Parra, M., and Cañal-Fernández, V. (2012). A fuzzy multi-objective approach for sustainable investments. Expert Systems with Applications, 39 (2012), 10904-10915. DOI:10.1016/j.eswa.2012.03.034

6. Boggia, A., and Cortina, C. (2010). Measuring sustainable development using a multi-criteria model: A case study. Journal of Environmental Management, 91(11), 2301-2306. DOI:10.1016/j.jenvman.2010.06.009

7. Bojadziev G, and Bojadziev M. (1995). Fuzzy Sets, Fuzzy Logic, Applications. Advances in Fuzzy Systems-Applications and Theory, 5, (Singapore: World Scientific).

8. Busch, T., Bauer, R., and Orlitzky, M. (2016). Sustainable Development and Financial Markets Old Paths and New Avenues. Business \& Society, 55(3), 303329. DOI: $10.1177 / 0007650315570701$.

9. Capelle-Blancard, G., and Monjon, S. (2012). Trends in the literature on socially responsible investment: looking for the keys under the lamppost. Business Ethics: A European Review, 21(3), 239-250. DOI: 10.1111/j.1467-8608.2012.01658.x

10. Capelle-Blancard, G., and Monjon, S. (2014). The performance of socially responsible funds: does the screening process matter?. European Financial Management. 20 (3), 494-520. DOI: 10.1111/j.1468-036X.2012.00643.x 
Preprint: Escrig-Olmedo, E., Rivera-Lirio, J. M., Muñoz-Torres, M. J., \& Fernández-Izquierdo, M. Á. (2017). Integrating multiple ESG investors' preferences into sustainable investment: A fuzzy multicriteria methodological approach. Journal of Cleaner Production, 162, 1334-1345.

11. Carrera, D., and Mayorga, R. (2008). Supply chain management: A modular Fuzzy Inference System approach in supplier selection for new product development. Journal of Intelligent Manufacturing, 19(1), 1-12. DOI 10.1007/s10845-007-00419

12. Chatterji, A. K., Levine, D. I., and Toffel, M.W. (2009). How well do social ratings actually measure corporate social responsibility?. Journal of Economics \& Management Strategy, 18, 125-169. DOI: 10.1111/j.1530-9134.2009.00210.x

13. Cronqvist, H., Siegel, S., and Yu, F. (2015). Value versus growth investing: Why do different investors have different styles?. Journal of Financial Economics, 117(2), 333-349. DOI:10.1016/j.jfineco.2015.04.006

14. Dam, L., and Scholtens, B. (2015). Toward a theory of responsible investing: On the economic foundations of corporate social responsibility. Resource and Energy Economics, 41, 103-121. http://dx.doi.org/10.1016/j.reseneeco.2015.04.008

15. Derwall, J., Koedijk, K., and Ter Horst, J. (2011). A tale of values-driven and profit-seeking social investors. Journal of Banking \& Finance, 35(8), 2137-2147. DOI:10.1016/j.jbankfin.2011.01.009

16. Duuren, E., Plantinga, A., and Scholtens, B. (2015). ESG integration and the investment management process: fundamental investing reinvented. Journal of Business Ethics, 1-9. DOI: 10.1007/s10551-015-2610-8

17. Endrikat, J., Guenther, E. and Hoppe, H. (2014). Making sense of conflicting empirical findings: A meta-analytic review of the relationship between corporate environmental and financial performance. European Management Journal 32(5), 735-751. DOI:10.1016/j.emj.2013.12.004 
Preprint: Escrig-Olmedo, E., Rivera-Lirio, J. M., Muñoz-Torres, M. J., \& Fernández-Izquierdo, M. Á. (2017). Integrating multiple ESG investors' preferences into sustainable investment: A fuzzy multicriteria methodological approach. Journal of Cleaner Production, 162, 1334-1345.

18. Erol, I., Sencer, S., Sari, R. (2011). A new fuzzy multi-criteria framework for measuring sustainability performance of a supply chain. Ecological Economics, 70(6), 1088-1100. DOI:10.1016/j.ecolecon.2011.01.001

19. Escrig-Olmedo, E., Muñoz-Torres, M. J., Fernández-Izquierdo, M. Á., and RiveraLirio, J. M. (2014). Lights and shadows on sustainability rating scoring. Review of Managerial Science, 8(4), 559-574. DOI 10.1007/s11846-013-0118-0

20. Escrig-Olmedo, E., Muñoz-Torres, M. J., Fernández-Izquierdo, M. Á., \& RiveraLirio, J. M. (2015). Measuring Corporate Environmental Performance: A Methodology for Sustainable Development. Business Strategy and the Environment. DOI: 10.1002/bse.1904.

21. EUROSIF (2010). European SRI Study 2010. Available at: http://www.eurosif.org/publication/european-sri-study-2010/ [accessed $18 / 05 / 2015]$

22. EUROSIF (2014). European SRI Study. Available at: http://www.eurosif.org/ourwork/research/sri/european-sri-study-2014/ [accessed 18/05/2015].

23. Ferrero-Ferrero, I, Fernández-Izquierdo, M.A., and Muñoz-Torres, M.J. (2016). The Effect of Environmental, Social and Governance Consistency on Economic Results. Sustainability, 8(10), 1005, 1-16. DOI: doi:10.3390/su8101005

24. Guyatt, D. (2005). Meeting objectives and resisting conventions: A focus on institutional investors and long-term responsible investing. Corporate Governance: The international journal of business in society, 5(3), 139-150. DOI $10.1108 / 14720700510604779$ 
Preprint: Escrig-Olmedo, E., Rivera-Lirio, J. M., Muñoz-Torres, M. J., \& Fernández-Izquierdo, M. Á. (2017). Integrating multiple ESG investors' preferences into sustainable investment: A fuzzy multicriteria methodological approach. Journal of Cleaner Production, 162, 1334-1345.

25. Himick, D., and Audousset-Coulier, S. (2015). Responsible Investing of Pension Assets: Links between Framing and Practices for Evaluation. Journal of Business Ethics, 1-18. DOI 10.1007/s10551-014-2530-z

26. Humphrey, J. E., Warren, G. J., and Boon, J. (2015). What is different about socially responsible funds? A holdings-based analysis. Journal of Business Ethics, 1-15. DOI 10.1007/s 10551-015-2583-7

27. Hurson, C., and Zopounidis, C. (1995). On the use of multicriteria decision aid methods to portfolio selection. Journal of Euro-Asian Management, 1(2), 69-94.

28. Husted, B. W., and de Sousa-Filho, J. M. (2016). The impact of sustainability governance, country stakeholder orientation, and country risk on environmental, social, and governance performance. Journal of Cleaner Production. DOI:10.1016/j.jclepro.2016.10.025

29. Jang J-S R. (1993). ANFIS: Adaptative-network-based Fuzzy Inference System. IEEE Transactions on Systems, Man, and Cybernetics, 23(3), 665-685. DOI $10.1109 / 21.256541$

30. Juravle, C., and Lewis, A. (2008). Identifying impediments to SRI in Europe: a review of the practitioner and academic literature. Business Ethics: A European Review, 17(3), 285-310. DOI: 10.1111/j.1467-8608.2008.00536.x

31. Krajnc, D., and Glavic, P. (2005). How to compare on relevant dimensions of sustainability. Ecological Economics, 55, 551-563. DOI:10.1016/j.ecolecon.2004.12.011

32. Kranjac, M., Henny, C., and Sikimic, U. (2012). Do European funds generate countries' sustainable development?. Actual Problems of Economics, 5(31), 386396. 
Preprint: Escrig-Olmedo, E., Rivera-Lirio, J. M., Muñoz-Torres, M. J., \& Fernández-Izquierdo, M. Á. (2017). Integrating multiple ESG investors' preferences into sustainable investment: A fuzzy multicriteria methodological approach. Journal of Cleaner Production, 162, 1334-1345.

33. Kumar, A. (2009). Dynamic style preferences of individual investors and stock returns. Journal of Financial and Quantitative Analysis, 44(03), 607-640. DOI: 10. $1017 / \mathrm{S} 0022109009990020$

34. Lee, CC. (1990). Fuzzy Logic in Control Systems: Fuzzy Logic controller, Part II, IEEE Transactions on Systems, Man, and Cybernetics, 20(2), 419-435. DOI:419435. $10.1109 / 21.52552$

35. Miras-Rodríguez, M.D.M., Carrasco-Gallego, A., and Escobar-Pérez, B. (2015). Has the CSR engagement of electrical companies had an effect on their performance? A closer look at the environment. Business Strategy and the Environment, 24(8), 819-835. DOI: 10.1002/bse.1848

36. Muñoz, M.J., Rivera, J.M., and Moneva, J.M. (2008). Evaluating Sustainability in Organizations with A Fuzzy Logic Approach. Industrial Management and Data Systems, 108 (6), 829-841. DOI: http://dx.doi.org/10.1108/02635570810884030

37. Neubaum, D.O. Zahra. S.A. (2006). Institutional ownership and corporate social performance: The moderating effects of investment horizon, activism, and coordination. Journal of Management, 32.1 (2006), 108-131.

38. Nilsson, J. (2009). Segmenting socially responsible mutual fund investors: The influence of financial return and social responsibility. International Journal of Bank Marketing, 27, 5-31. DOI:10.1108/02652320910928218

39. Orsato, R. J., Garcia, A., Mendes-Da-Silva, W., Simonetti, R., and Monzoni, M. (2015). Sustainability indexes: why join in? A study of the 'Corporate Sustainability Index (ISE)'in Brazil. Journal of Cleaner Production, 96, 161-170. DOI:10.1016/j.jclepro.2014.10.071 
Preprint: Escrig-Olmedo, E., Rivera-Lirio, J. M., Muñoz-Torres, M. J., \& Fernández-Izquierdo, M. Á. (2017). Integrating multiple ESG investors' preferences into sustainable investment: A fuzzy multicriteria methodological approach. Journal of Cleaner Production, 162, 1334-1345.

40. Ortas, E., Álvarez, I., Jaussaud, J., and Garayar, A. (2015). The impact of institutional and social context on corporate environmental, social and governance performance of companies committed to voluntary corporate social responsibility initiatives. Journal of Cleaner Production, 108, 673-684. DOI:10.1016/j.jclepro.2015.06.089

41. Phillis, Y.A., and Andriantiatsaholiniaina L. A. (2001). Sustainability: An IllDefined Concept and Its Assessment Using Fuzzy Logic. Ecological Economics, 37(3), 435-456. DOI: 10.1016/S0921-8009(00)00290-1

42. Phillis, YA., and Davis BJ. (2009). Assessment of corporate sustainability via Fuzzy Logic. Journal of Intelligent and Robotic Systems, 55(1), 3-20. DOI $10.1007 / \mathrm{s} 10846-008-9289-3$

43. Phillis, Y. A., Grigoroudis, E., and Kouikoglou, V. S. (2011). Sustainability ranking and improvement of countries. Ecological Economics, 70(3), 542-553. DOI:10.1016/j.ecolecon.2010.09.037

44. Praestbro, K., and Winther, R. (2011). CSR and mainstream investing: A new match? - An analysis of the existing ESG integration methods in theory and practice and the way forward. Journal of Sustainable Finance \& Investment, 1 (34), 209-221. DOI:10.1080/20430795.2012.655889

45. Prato, T., (2003). Multiple-attribute evaluation of ecosystem management for the Missouri River system. Ecological Economics, 45, 297-309. . DOI:10.1016/S09218009(03)00077-6

46. Renneboog, L., Ter Horst, J., and Zhang, C. (2008). Socially responsible investments: Institutional aspects, performance, and investor behaviour. Journal of Banking \& Finance, 32 (9), 1723-17428. . DOI:10.1016/j.jbankfin.2007.12.039 
Preprint: Escrig-Olmedo, E., Rivera-Lirio, J. M., Muñoz-Torres, M. J., \& Fernández-Izquierdo, M. Á. (2017). Integrating multiple ESG investors' preferences into sustainable investment: A fuzzy multicriteria methodological approach. Journal of Cleaner Production, 162, 1334-1345.

47. Revelli, C., and Viviani, J. L. (2015). Financial performance of socially responsible investing (SRI): what have we learned? A meta - analysis. Business Ethics: $A$ European Review, 24(2), 158-185. DOI: 10.1111/beer.12076

48. Rivera, J.M., and Muñoz, M.J. (2010). The Effectiveness of the Public Support Policies for the European Industry Financing as a Contribution to Sustainable Development. Journal of Business Ethics, 94 (4), 489-515. DOI 10.1007/s10551009-0278-7

49. Saghafian S, and Hejazi S.R. (2005). Multi-Criteria Group Decision Making Using A Modified Fuzzy TOPSIS Procedure, IEEE Computer Society, [Proc. of the 2005 International Conf. on Computational Intelligence for Modeling, Control and Automation and International Conference on Intelligent Agents, Web Technologies and Internet Commerce] (Vol. 2, pp. 215-221). IEEE.

50. Schäfer, H., Beer, J., Zenker, J., and Fernandes, P. (2006). Who is Who in Corporate Social Responsibility Rating? A Survey of Internationally Established Rating Systems that Measure Corporate Responsibility. Bertelsmann Foundation: Gütersloh.

51. Scholtens, B. (2014). Indicators of responsible investing. Ecological Indicators, 36, 382-385. doi:10.1016/j.ecolind.2013.08.012

52. Sevastjanov, P., and Dymova, L. (2009). Stock screening with use of multiple criteria decision making and optimization. Omega, 37, 659-671. doi:10.1016/j.omega.2008.04.002

53. Sievänen, R. (2014). Practicalities bottleneck to pension fund responsible investment?. Business Ethics: A European Review, 23(3), 309-326. DOI: 10.1111/beer. 12048 
Preprint: Escrig-Olmedo, E., Rivera-Lirio, J. M., Muñoz-Torres, M. J., \& Fernández-Izquierdo, M. Á. (2017). Integrating multiple ESG investors' preferences into sustainable investment: A fuzzy multicriteria methodological approach. Journal of Cleaner Production, 162, 1334-1345.

54. Statman, M. (2008). Quiet conversations: The expressive nature of socially responsible investors. Journal of Financial Planning, 21 (2), 40-46.

55. Tahera, K., Ibrahim, R.N., and Lochert, P.B. (2008). A fuzzy logic approach for dealing with qualitative quality characteristics of a process. Expert Systems with Applications: An International Journal, 34(4), 2630-2638. DOI:10.1016/j.eswa.2007.05.025

56. Tiryaki, F., and Ahlatcioglu, M. (2005). Fuzzy stock selection using a new fuzzy ranking and weighting algorithm. Applied Mathematics and Computation, 170, 144-157. DOI:10.1016/j.amc.2004.10.092

57. Trinks, P. J., and Scholtens, B. (2015). The Opportunity Cost of Negative Screening in Socially Responsible Investing. Journal of Business Ethics, 1-16. DOI: $10.1007 / \mathrm{s} 10551-015-2684-3$

58. US-SIF (2014). US Sustainable, Responsible and Impact Investing Trends (2014). Available at: http://www.ussif.org/Files/Publications/SIF_Trends_14.F.ES.pdf [accessed 18/05/2015].

59. Utz, S., Wimmer, M., and Steuer, R. E. (2015). Tri-criterion modeling for constructing more-sustainable mutual funds. European Journal of Operational Research, 246(1), 331-338. DOI 10.1016/j.ejor.2015.04.035

60. Vveinhardt, J., and Gulbovaite, E. (2015). Expert Evaluation of Diagnostic Instrument for Personal and Organizational Value Congruence. Journal of Business Ethics, DOI 10.1007/s10551-014-2527-7.

61. Walls, J.L., Berrone, P., and Phan, P.H. (2012). Corporate governance and environmental performance: is there really a link?. Strategic Management Journal, 33(8), 885-913. DOI: 10.1002/smj. 
Preprint: Escrig-Olmedo, E., Rivera-Lirio, J. M., Muñoz-Torres, M. J., \& Fernández-Izquierdo, M. Á. (2017). Integrating multiple ESG investors' preferences into sustainable investment: A fuzzy multicriteria methodological approach. Journal of Cleaner Production, 162, 1334-1345.

62. Wang, YM., and Elhag, TMS. (2006). Fuzzy TOPSIS method based on alpha level sets with an application to bridge risk assessment. Expert Systems with Applications, 31(2), 309-319. doi:10.1016/j.eswa.2005.09.040

63. Waring, P., and Edwards, T. (2008). Socially responsible investment: Explaining its uneven development and human resource management consequences. Corporate Governance: An International Review, 16(3), 135-145. doi:10.1111/j.14678683.2008.00676.x

64. Wood, R., and Zaichkowsky, J.L. (2004). Attitudes and trading behavior of stock market investors: A segmentation approach. Journal of Behavioral Finance, 5(3), 170-179. DOI:10.1207/s15427579jpfm0503_5

65. Wu, W-W., and Lee, Y-T. (2007). Developing global managers' competencies using the Fuzzy DEMATEL method. Expert Systems with Applications, 32 (2), 499-507. doi:10.1016/j.eswa.2005.12.005

66. Yang, T., and Hung, C-C. (2007). Multiple-attribute decision making methods for plant layout design problem. Robotics and Computer-Integrated Manufacturing, 23(1), 126-137. doi:10.1016/j.rcim.2005.12.002 
Preprint: Escrig-Olmedo, E., Rivera-Lirio, J. M., Muñoz-Torres, M. J., \& Fernández-Izquierdo, M. Á. (2017). Integrating multiple ESG investors' preferences into sustainable investment: A fuzzy multicriteria methodological approach. Journal of Cleaner Production, 162, 1334-1345.

\section{Tables}

Table 1. Studies about segments of SR investors

\begin{tabular}{|c|c|c|}
\hline Study & Segmentation variables & Segments of SR-investors \\
\hline $\begin{array}{l}\text { Wood and } \\
\text { Zaichkowsky } \\
(2004)\end{array}$ & $\begin{array}{ll}\text { (i) Investment horizon } \\
\text { (ii) Risk attitude } \\
\text { (iii) Personalization of } \\
\text { loss } \\
\text { (iv) Confidence } \\
\text { (v) Control }\end{array}$ & $\begin{array}{l}\text { (i) 'Risk-intolerant' traders. This segment showed a } \\
\text { low tolerance for risk in their portfolio and traded } \\
\text { little. } \\
\text { (ii) 'Confident traders'. A segment characterized by } \\
\text { high levels of confidence and control. } \\
\text { (iii) 'Loss-averse young traders'. This segment is } \\
\text { characterized by high levels of personalization of } \\
\text { loss and low levels of confidence and control. } \\
\text { (iv) 'Conservative long-term investors'. A group that } \\
\text { has a longer investment horizon than the other } \\
\text { groups. }\end{array}$ \\
\hline Nilsson (2009) & $\begin{array}{l}\text { (ii) Socio-demographic } \\
\text { (iii) Attitudinal } \\
\text { (iv) Behavioural } \\
\text { profiling }\end{array}$ & $\begin{array}{l}\text { (i) The 'primarily concerned about profit' SR } \\
\text { investors value financial return over social } \\
\text { responsibility. } \\
\text { (ii) The 'primarily concerned about social } \\
\text { responsibility' investors value social } \\
\text { responsibility over financial return. } \\
\text { (iii) The 'socially responsible and return driven' SR } \\
\text { investors value both return and social } \\
\text { responsibility when deciding to invest in SRI. }\end{array}$ \\
\hline $\begin{array}{l}\text { Praestbro and } \\
\text { Winther (2011) }\end{array}$ & $\begin{array}{ll}\text { (i) } & \text { ESG data } \\
\text { (ii) } & \text { Financial data }\end{array}$ & $\begin{array}{l}\text { (i) Investors belong to a 'single decision model' in } \\
\text { which only financial data are valued. } \\
\text { (ii) Investors belong to a 'dual decision model' in } \\
\text { which both financial data and ESG factors are } \\
\text { considered sequentially. }\end{array}$ \\
\hline $\begin{array}{l}\text { Derwall et al. } \\
\text { (2011) }\end{array}$ & $\begin{array}{ll}\text { (i) } & \text { Pecuniary } \\
& \text { motivations } \\
\text { (ii) } & \begin{array}{l}\text { Non-pecuniary } \\
\text { motivations }\end{array}\end{array}$ & $\begin{array}{l}\text { (i) 'Values-driven orientation'. An investment } \\
\text { approach in which social and personal values } \\
\text { instead of financial considerations are the basis } \\
\text { for the decision to integrate CSR criteria into } \\
\text { investment decisions. This view implies that } \\
\text { investors accept a loss in financial performance. } \\
\text { (ii) 'Profit-seeking orientation'. An investment } \\
\text { approach that accommodates investors in their } \\
\text { pursuit of traditional financial goals. This view } \\
\text { implies that investors accord precedence to good } \\
\text { financial performance but do not neglect ESG } \\
\text { aspects. }\end{array}$ \\
\hline $\begin{array}{l}\text { Ballestero et al. } \\
\text { (2012) }\end{array}$ & $\begin{array}{l}\text { Environmentally } \\
\text { responsible investment }\end{array}$ & $\begin{array}{l}\text { (i) Strong green investor. High level of aspiration for } \\
\text { the ethical (green) goal. } \\
\text { (ii) Weak green investor. Low level of aspiration for } \\
\text { the ethical (green) goal. }\end{array}$ \\
\hline $\begin{array}{l}\text { Bush et al. } \\
\text { (2015) based on } \\
\text { Chatterji et al. } \\
\text { (2009) }\end{array}$ & $\begin{array}{ll}\text { (i) } & \text { Financial } \\
& \text { motivations } \\
\text { (ii) } & \begin{array}{l}\text { Non-financial } \\
\text { motivations }\end{array}\end{array}$ & $\begin{array}{l}\text { (i) 'Financial investors' seek to achieve superior } \\
\text { financial performance by relying on ESG criteria. } \\
\text { (ii) 'Deontological investors' do not want to support } \\
\text { irresponsible business practices. } \\
\text { (iii) 'Consequential investors' seek to influence firms } \\
\text { by directing their investments to more sustainable } \\
\text { firms. } \\
\text { (iv) 'Expressive investors' focus on sustainable } \\
\text { investments as a mechanism of enhancing their } \\
\text { own social identity. }\end{array}$ \\
\hline
\end{tabular}


Preprint: Escrig-Olmedo, E., Rivera-Lirio, J. M., Muñoz-Torres, M. J., \& Fernández-Izquierdo, M. Á. (2017). Integrating multiple ESG investors' preferences into sustainable investment: A fuzzy multicriteria methodological approach. Journal of Cleaner Production, 162, 1334-1345.

Table 2. Linguistic variables for the relative importance weights of four criteria

\begin{tabular}{ll}
\hline \multicolumn{1}{c}{ Linguistic Variables } & \multicolumn{1}{c}{ Membership Functions } \\
\hline Very Low $(\mathrm{VL})$ & $(0,0,0.25)$ \\
Low $(\mathrm{L})$ & $(0,0.25,0.5)$ \\
Medium $(\mathrm{M})$ & $(0.25,0.5,0.75)$ \\
High $(\mathrm{H})$ & $(0.5,0.75,1)$ \\
Very High $(\mathrm{VH})$ & $(0.75,1,1)$ \\
\hline
\end{tabular}


Preprint: Escrig-Olmedo, E., Rivera-Lirio, J. M., Muñoz-Torres, M. J., \& Fernández-Izquierdo, M. Á. (2017). Integrating multiple ESG investors' preferences into sustainable investment: A fuzzy multicriteria methodological approach. Journal of Cleaner Production, 162, 1334-1345.

Table 3. Linguistic variables for the ratings

\begin{tabular}{ll}
\hline \multicolumn{1}{c}{ Linguistic Variables } & \multicolumn{1}{c}{ Membership Functions } \\
\hline Poor Sustainability (PS) & $(0,0,0.25)$ \\
Low Sustainability (LS) & $(0,0.25,0.5)$ \\
Medium Sustainability (MS) & $(0.25,0.5,0.75)$ \\
High Sustainability (HS) & $(0.5,0.75,1)$ \\
Top Sustainability (TS) & $(0.75,1,1)$ \\
\hline
\end{tabular}


Preprint: Escrig-Olmedo, E., Rivera-Lirio, J. M., Muñoz-Torres, M. J., \& Fernández-Izquierdo, M. Á. (2017). Integrating multiple ESG investors' preferences into sustainable investment: A fuzzy multicriteria methodological approach. Journal of Cleaner Production, 162, 1334-1345.

Table 4. The relative importance weights of the four criteria by 3 DMs per scenario

\begin{tabular}{|c|c|c|c|c|}
\hline \multicolumn{5}{|c|}{ Scenario 1} \\
\hline Criterion & $\mathrm{DM}_{1.1}$ & $\mathrm{DM}_{1.2 .}$ & $\mathrm{DM}_{1.3}$ & $\begin{array}{l}\text { Aggregated fuzzy } \\
\text { number }\end{array}$ \\
\hline $\mathrm{C} 1=\mathrm{F}$ & VH & $\mathrm{H}$ & $\mathrm{VH}$ & $(0.67,0.92,1.00)$ \\
\hline$C 2=E$ & $\mathrm{~L}$ & VH & $\mathrm{H}$ & $(0.42,0.58,0.75)$ \\
\hline $\mathrm{C} 3=\mathrm{S}$ & $\mathrm{L}$ & VH & $\mathrm{H}$ & $(0.42,0.58,0.75)$ \\
\hline $\mathrm{C4}=\mathrm{G}$ & $\mathrm{H}$ & $\mathrm{VH}$ & $\mathrm{H}$ & $(0.58,0.83,1.00)$ \\
\hline \multicolumn{5}{|c|}{ Scenario 2} \\
\hline Criterion & $\mathrm{DM}_{2.1}$ & $\mathrm{DM}_{2.2}$ & $\mathrm{DM}_{2.3}$ & $\begin{array}{l}\text { Aggregated fuzzy } \\
\text { number }\end{array}$ \\
\hline $\mathrm{C} 1=\mathrm{F}$ & $\mathrm{M}$ & $\mathrm{H}$ & $\mathrm{M}$ & $(0.33,0.58,0.83)$ \\
\hline $\mathrm{C} 2=\mathrm{E}$ & VH & VH & VH & $(0.75,1.00,1.00)$ \\
\hline $\mathrm{C} 3=\mathrm{S}$ & $\mathrm{H}$ & M & VH & $(0.50,0.75,0.92)$ \\
\hline $\mathbf{C 4}=\mathbf{G}$ & $\mathrm{L}$ & VH & $\mathrm{H}$ & $(0.42,0.67,0.83)$ \\
\hline
\end{tabular}


Preprint: Escrig-Olmedo, E., Rivera-Lirio, J. M., Muñoz-Torres, M. J., \& Fernández-Izquierdo, M. Á. (2017). Integrating multiple ESG investors' preferences into sustainable investment: A fuzzy multicriteria methodological approach. Journal of Cleaner Production, 162, 1334-1345.

Table 5. Ratings of the first four companies in the four criteria by 3 DMs per scenario

\begin{tabular}{|c|c|c|c|c|c|c|}
\hline \multicolumn{7}{|c|}{ Scenario 1} \\
\hline Criteria & Company & & $\mathbf{D M}_{1}$ & $\mathbf{D M}_{2}$ & $\mathrm{DM}_{3}$ & $\begin{array}{c}\text { Aggregated fuzzy } \\
\text { number }\end{array}$ \\
\hline \multirow{4}{*}{$\mathrm{C}_{1}=\mathrm{F}$} & $\mathrm{A}_{1}$ & PS & & PS & PS & $(0.00,0.00,0.25)$ \\
\hline & $\mathrm{A}_{2}$ & PS & & PS & PS & $(0.00,0.00,0.25)$ \\
\hline & $\mathrm{A}_{3}$ & $\mathrm{LS}$ & & $\mathrm{LS}$ & LS & $(0.00,0.25,0.50)$ \\
\hline & $\mathrm{A}_{4}$ & PS & & PS & PS & $(0.00,0.00,0.25)$ \\
\hline & $\ldots$ & & $\cdots$ & $\ldots$ & & $\ldots$ \\
\hline \multirow[t]{4}{*}{$\mathbf{C}_{2}=\mathbf{E}$} & $\mathrm{A}_{1}$ & PS & & PS & PS & $(0.00,0.00,0.25)$ \\
\hline & $\mathrm{A}_{2}$ & PS & & PS & PS & $(0.00,0.00,0.25)$ \\
\hline & $\mathrm{A}_{3}$ & HS & & MS & MS & $(0.33,0.58,0.83)$ \\
\hline & $\mathrm{A}_{4}$ & PS & & PS & PS & $(0.00,0.00,0.25)$ \\
\hline \multirow{5}{*}{$\mathrm{C}_{3}=\mathrm{S}$} & $\cdots$ & & $\ldots$ & $\ldots$ & & $\cdots$ \\
\hline & $\mathrm{A}_{1}$ & $\mathrm{LS}$ & & PS & PS & $(0.00,0.08,0.33)$ \\
\hline & $\mathrm{A}_{2}$ & HS & & MS & MS & $(0.33,0.58,0.83)$ \\
\hline & $\mathrm{A}_{3}$ & MS & & $\mathrm{LS}$ & LS & $(0.08,0.33,0.58)$ \\
\hline & $\mathrm{A}_{4}$ & PS & & PS & PS & $(0.00,0.00,0.25)$ \\
\hline & $\ldots$ & & $\ldots$ & $\ldots$ & & $\cdots$ \\
\hline \multirow[t]{5}{*}{$\mathrm{C}_{4}=\mathrm{G}$} & $\mathrm{A}_{1}$ & HS & & MS & HS & $(0.42,0.67,0.92)$ \\
\hline & $\mathrm{A}_{2}$ & HS & & MS & HS & $(0.42,0.67,0.92)$ \\
\hline & $\mathrm{A}_{3}$ & HS & & HS & HS & $(0.50,0.75,1.00)$ \\
\hline & $\mathrm{A}_{4}$ & PS & & PS & PS & $(0.00,0.00,0.25)$ \\
\hline & $\ldots$ & & $\ldots$ & $\ldots$ & & $\ldots$ \\
\hline \multicolumn{7}{|c|}{ Scenario 2} \\
\hline Criteria & Company & & $\mathbf{D M}_{1}$ & $\mathbf{D M}_{2}$ & $\mathrm{DM}_{3}$ & $\begin{array}{c}\text { Aggregated fuzzy } \\
\text { number }\end{array}$ \\
\hline \multirow[t]{4}{*}{$\mathrm{C}_{1}=\mathrm{F}$} & $\overline{A_{1}}$ & $\mathrm{LS}$ & & PS & $\mathrm{LS}$ & $(0.00,0.17,0.42)$ \\
\hline & $\mathrm{A}_{2}$ & PS & & PS & PS & $(0.00,0.00,0.25)$ \\
\hline & $\mathrm{A}_{3}$ & MS & & LS & MS & $(0.17,0.42,0.67)$ \\
\hline & $\mathrm{A}_{4}$ & LS & & PS & LS & $(0.00,0.17,0.42)$ \\
\hline \multirow[t]{4}{*}{$\mathbf{C}_{2}=\mathbf{E}$} & $\cdots$ & PS & $\cdots$ & PS & PS & $\begin{array}{l}\cdots \\
(0.00,0.00,0.25)\end{array}$ \\
\hline & $\mathrm{A}_{2}$ & PS & & PS & PS & $(0.00,0.00,0.25)$ \\
\hline & $\mathrm{A}_{3}$ & MS & & MS & MS & $(0.25,0.50,0.75)$ \\
\hline & $\mathrm{A}_{4}$ & PS & & PS & PS & $(0.00,0.00,0.25)$ \\
\hline \multirow{4}{*}{$\mathrm{C}_{3}=\mathrm{S}$} & $\cdots$ & & $\ldots$ & $\ldots$ & & \\
\hline & $\begin{array}{l}\mathrm{A}_{1} \\
\mathrm{~A}_{2}\end{array}$ & $\begin{array}{l}\text { PS } \\
\text { MS }\end{array}$ & & $\begin{array}{l}\text { MS } \\
\text { HS }\end{array}$ & $\begin{array}{l}\text { PS } \\
\text { MS }\end{array}$ & $\begin{array}{l}(0.08,0.17,0.42) \\
(0.33,0.58,0.83)\end{array}$ \\
\hline & $\mathrm{A}_{3}$ & LS & & MS & $\mathrm{LS}$ & $(0.08,0.33,0.58)$ \\
\hline & $\mathrm{A}_{4}$ & PS & & PS & PS & $(0.00,0.00,0.25)$ \\
\hline \multirow{5}{*}{$\mathrm{C}_{4}=\mathrm{G}$} & $\cdots$ & HS & $\cdots$ & $\cdots$ & HS & $\cdots$ \\
\hline & $\mathrm{A}_{2}$ & HS & & HS & HS & $(0,05,0.75,1.00)$ \\
\hline & $\mathrm{A}_{3}$ & $\mathrm{TS}$ & & $\mathrm{HS}$ & HS & $(0.58,0.83,1.00)$ \\
\hline & $\mathrm{A}_{4}$ & PS & & PS & PS & $(0.00,0.00,0.25)$ \\
\hline & $\ldots$ & & $\ldots$ & $\ldots$ & & $\ldots$ \\
\hline
\end{tabular}


Preprint: Escrig-Olmedo, E., Rivera-Lirio, J. M., Muñoz-Torres, M. J., \& Fernández-Izquierdo, M. Á. (2017). Integrating multiple ESG investors' preferences into sustainable investment: A fuzzy multicriteria methodological approach. Journal of Cleaner Production, 162, 1334-1345.

Table 6. The fuzzy normalized decision matrix and fuzzy weights of four alternatives per scenario

\begin{tabular}{|c|c|c|c|c|}
\hline \multicolumn{5}{|c|}{ Scenario 1} \\
\hline Companies & $\mathrm{C}_{1}=\mathrm{F}$ & $\mathrm{C}_{2}=\mathrm{E}$ & $\mathrm{C}_{3}=\mathrm{S}$ & $\mathrm{C}_{4}=\mathrm{G}$ \\
\hline $\mathrm{A}_{1}$ & $(0.00,0.00,0.25)$ & $(0.00,0.00,0.25)$ & $(0.00,0.08,0.33)$ & $(0.42,0.67,0.92)$ \\
\hline $\mathrm{A}_{2}$ & $(0.00,0.00,0.25)$ & $(0.00,0.00,0.25)$ & $(0.33,0.58,0.83)$ & $(0.42,0.67,0.92)$ \\
\hline $\mathrm{A}_{3}$ & $(0.00,0.25,0.50)$ & $(0.33,0.58,0.83)$ & $(0.08,0.33,0.58)$ & $(0.50,0.75,1.00)$ \\
\hline $\mathrm{A}_{4}$ & $(0.00,0.00,0.25)$ & $(0.00,0.00,0.25)$ & $(0.00,0.00,0.25)$ & $(0.00,0.00,0.25)$ \\
\hline$\ldots$ & & & & \\
\hline $\mathrm{A}_{52}$ & $(0.58,0.83,1.00)$ & $(0.42,0.67,0.92)$ & $(0.00,0.25,0.50)$ & $(0.00,0.17,0.42)$ \\
\hline Weight & $(0.67,0.92,1.00)$ & $(0.42,0.58,0.75)$ & $(0.42,0.58,0.75)$ & $(0.58,0.83,1.00)$ \\
\hline \multicolumn{5}{|c|}{ Scenario 2} \\
\hline Companies & $\mathrm{C}_{1}=\mathrm{F}$ & $\mathrm{C}_{2}=\mathrm{E}$ & $\mathrm{C}_{3}=\mathrm{S}$ & $\mathrm{C}_{4}=\mathrm{G}$ \\
\hline $\mathrm{A}_{1}$ & $(0.00,0.17,0.42)$ & $(0.00,0.00,0.25)$ & $(0.08,0.17,0.42)$ & $(0.50,0.75,1.00)$ \\
\hline $\mathrm{A}_{2}$ & $(0.00,0.00,0.25)$ & $(0.00,0.00,0.25)$ & $(0.33,0.58,0.83)$ & $(0.50,0.75,1.00)$ \\
\hline $\mathrm{A}_{3}$ & $(0.17,0.42,0.67)$ & $(0.25,0.50,0.75)$ & $(0.08,0.33,0.58)$ & $(0.58,0.83,1.00)$ \\
\hline $\mathrm{A}_{4}$ & $(0.00,0.17,0.42)$ & $(0.00,0.00,0.25)$ & $(0.00,0.00,0.25)$ & $(0.00,0.00,0.25)$ \\
\hline$\cdots$ & $\cdots$ & $\begin{array}{c}\cdots \\
\cdots\end{array}$ & & \\
\hline $\mathrm{A}_{52}$ & $(0.67,0.92,1.00)$ & $(0.25,0.50,0.75)$ & $(0.00,0.25,0.50)$ & $(0.00,0.17,0.42)$ \\
\hline Weight & $(0.33,0.58,0.83)$ & $(0.75,1.00,1.00)$ & $(0.50,0.75,0.92)$ & $(0.42,0.67,0.83)$ \\
\hline
\end{tabular}


Preprint: Escrig-Olmedo, E., Rivera-Lirio, J. M., Muñoz-Torres, M. J., \& Fernández-Izquierdo, M. Á. (2017). Integrating multiple ESG investors' preferences into sustainable investment: A fuzzy multicriteria methodological approach. Journal of Cleaner Production, 162, 1334-1345.

Table 7. The fuzzy weighted, normalized decision matrix per scenario

\begin{tabular}{ccccc}
\hline \multicolumn{5}{c}{ Scenario 1} \\
\hline Companies & $\mathbf{C}_{\mathbf{1}}=\mathbf{F}$ & $\mathbf{C}_{\mathbf{2}}=\mathbf{E}$ & $\mathbf{C}_{\mathbf{3}}=\mathbf{S}$ & $\mathbf{C}_{\mathbf{4}}=\mathbf{G}$ \\
\hline $\mathrm{A}_{1}$ & $(0.00,0.00,0.25)$ & $(0.00,0.00,0.19)$ & $(0.00,0.05,0.25)$ & $(0.24,0.56,0.92)$ \\
$\mathrm{A}_{2}$ & $(0.00,0.00,0.25)$ & $(0.00,0.00,0.19)$ & $(0.14,0.34,0.63)$ & $(0.24,0.56,0.92)$ \\
$\mathrm{A}_{3}$ & $(0.00,0.23,0.50)$ & $(0.14,0.34,0.63)$ & $(0.03,0.19,0.44)$ & $(0.29,0.63,1.00)$ \\
$\mathrm{A}_{4}$ & $(0.00,0.00,0.25)$ & $(0.00,0.00,0.19)$ & $(0.00,0.00,0.19)$ & $(0.00,0.00,0.25)$ \\
$\ldots$ & $\ldots$ & $\ldots$ & $\ldots$ & $\ldots$ \\
$\mathrm{A}_{52}$ & $(0.39,0.76,1.00)$ & $(0.17,0.39,0.69)$ & $(0.00,0.15,0.38)$ & $(0.00,0.14,0.42)$ \\
\hline \multicolumn{7}{c}{$\mathbf{C}_{\mathbf{1}}=\mathbf{F}$} & Scenario 2 & & \\
\hline Companies & $(0.00,0.10,0.35)$ & $(0.00,0.00,0.25)$ & $(0.04,0.13,0.38)$ & $(0.21,0.50,0.83)$ \\
$\mathrm{A}_{1}$ & $(0.00,0.00,0.21)$ & $(0.00,0.00,0.25)$ & $(0.17,0.44,0.76)$ & $(0.21,0.50,0.83)$ \\
$\mathrm{A}_{2}$ & $(0.06,0.24,0.56)$ & $(0.19,0.50,0.75)$ & $(0.04,0.25,0.53)$ & $(0.24,0.56,0.83)$ \\
$\mathrm{A}_{3}$ & $(0.00,0.10,0.35)$ & $(0.00,0.00,0.25)$ & $(0.00,0.20,0.23)$ & $(0.00,0.00,0.21)$ \\
$\mathrm{A}_{4}$ & $\ldots$ & $\ldots$ & $\ldots$ & $\ldots$ \\
$\ldots$ & $(0.22,0.53,0.83)$ & $(0.19,0.50,0.75)$ & $(0.00,0.19,0.46)$ & $(0.00,0.11,0.35)$ \\
$\mathrm{A}_{52}$ & & & &
\end{tabular}


Preprint: Escrig-Olmedo, E., Rivera-Lirio, J. M., Muñoz-Torres, M. J., \& Fernández-Izquierdo, M. Á. (2017). Integrating multiple ESG investors' preferences into sustainable investment: A fuzzy multicriteria methodological approach. Journal of Cleaner Production, 162, 1334-1345.

Table 8. The distance measurement per scenario

\begin{tabular}{cccc}
\hline \multicolumn{5}{c}{ Scenario 1 } \\
\hline Companies & $\mathbf{d}^{+}$ & $\mathbf{d}^{-}$ & $\mathbf{C C}$ \\
\hline $\mathrm{A}_{1}$ & 3,281877126 & 1,03419070 & 0,239614098 \\
$\mathrm{~A}_{2}$ & 3,037597397 & 1,30576028 & 0,300633836 \\
$\mathrm{~A}_{3}$ & 2,704653524 & 1,71465718 & 0,387991995 \\
$\mathrm{~A}_{4}$ & 3,731737648 & 0,50518149 & 0,119233214 \\
$\ldots$ & $\ldots$ & $\ldots$ & $\ldots$ \\
$\mathrm{A}_{52}$ & 2,672171436 & 1,713222918 & 0,390665646 \\
\hline \multicolumn{5}{c}{ Scenario 2} \\
\hline Companies & $\mathbf{d}^{+}$ & $\mathbf{d}^{-}$ & $\mathbf{C C}$ \\
\hline $\mathrm{A}_{1}$ & 3,1674853 & 1,15961643 & 0,26798918 \\
$\mathrm{~A}_{2}$ & 3,0052953 & 1,35572199 & 0,31087288 \\
$\mathrm{~A}_{3}$ & 2,58185332 & 1,8197958 & 0,413435 \\
$\mathrm{~A}_{4}$ & 3,65415855 & 0,60510727 & 0,14206844 \\
$\ldots$ & $\ldots$ & & $\ldots$ \\
$\mathrm{A}_{52}$ & 2,76790738 & 1,61382126 & 0,36830698 \\
\hline
\end{tabular}


Preprint: Escrig-Olmedo, E., Rivera-Lirio, J. M., Muñoz-Torres, M. J., \& Fernández-Izquierdo, M. Á. (2017). Integrating multiple ESG investors' preferences into sustainable investment: A fuzzy multicriteria methodological approach. Journal of Cleaner Production, 162, 1334-1345.

Table 9. An example of fuzzy TOPSIS MCDM rankings results vs. Asset4 rankings per scenario

Scenario 1

\begin{tabular}{|c|c|c|c|c|c|c|c|c|c|}
\hline COMPANY & $\begin{array}{l}\text { FUZZY } \\
\text { TOPSIS } \\
\text { SCORE }\end{array}$ & $\begin{array}{c}\text { FUZZY } \\
\text { TOPSIS } \\
\text { RANK } \\
\text { (I) } \\
\end{array}$ & $\begin{array}{l}\text { ASSET4 } \\
\text { SCORE }\end{array}$ & $\begin{array}{c}\text { ASSET4 } \\
\text { RANK } \\
\text { (II) }\end{array}$ & $\begin{array}{c}\text { DIF } \\
\text { (II-I) }\end{array}$ & $\begin{array}{c}\text { ECO } \\
\text { ASSET4 } \\
\text { SCORE }\end{array}$ & $\begin{array}{c}\text { ENV } \\
\text { ASSET4 } \\
\text { SCORE }\end{array}$ & $\begin{array}{c}\text { SOC } \\
\text { ASSET4 } \\
\text { SCORE }\end{array}$ & $\begin{array}{c}\text { GOV } \\
\text { ASSET4 } \\
\text { SCORE }\end{array}$ \\
\hline PVH & 0,634 & 1 & 0,919 & 1 & 0 & 0,8976 & 0,882 & 0,9664 & 0,93 \\
\hline $\begin{array}{l}\text { DAVIDJONES } \\
\text { DEFERRED }\end{array}$ & 0,600 & 2 & 0,818 & 5 & 3 & 0,886 & 0,722 & 0,7817 & 0,8837 \\
\hline GAP & 0,590 & 3 & 0,834 & 4 & 1 & 0,9691 & 0,7049 & 0,7165 & 0,9441 \\
\hline $\begin{array}{l}\text { GILDAN } \\
\text { ACTIVEWEAR }\end{array}$ & 0,573 & 4 & 0,868 & 2 & -2 & 0,6985 & 0,9037 & 0,9415 & 0,9294 \\
\hline MARKS\&SPENCER'B' & 0,564 & 5 & 0,846 & 3 & -2 & 0,615 & 0,916 & 0,931 & 0,9231 \\
\hline NORDSTROM & 0,530 & 6 & 0,792 & 6 & 0 & 0,6915 & 0,8421 & 0,8332 & 0,8021 \\
\hline NEXT & 0,526 & 7 & 0,779 & 8 & 1 & 0,5059 & 0,88 & 0,8738 & 0,8566 \\
\hline $\begin{array}{l}\text { RICHEMONT SECS. } \\
\text { (BER) }\end{array}$ & 0,516 & 8 & 0,789 & 7 & -1 & 0,9777 & 0,8274 & 0,9105 & 0,441 \\
\hline INDITEX & 0,500 & 9 & 0,758 & 9 & 0 & 0,5629 & 0,8508 & 0,9245 & 0,6938 \\
\hline $\mathrm{VF}$ & 0,485 & 10 & 0,727 & 10 & 0 & 0,7046 & 0,8392 & 0,5556 & 0,8083 \\
\hline TRUWORTHSINTL. & 0,478 & 11 & 0,697 & 13 & 2 & 0,7843 & 0,3995 & 0,9071 & 0,6988 \\
\hline LBRANDS & 0,471 & 12 & 0,655 & 14 & 2 & 0,6058 & 0,562 & 0,7205 & 0,7301 \\
\hline LOUIS VUITTON(EAS) & 0,466 & 13 & 0,702 & 12 & -1 & 0,6172 & 0,9078 & 0,9133 & 0,3695 \\
\hline PACIFICBRANDS & 0,464 & 14 & 0,722 & 11 & -3 & 0,7592 & 0,7958 & 0,5871 & 0,7451 \\
\hline FOSCHINI(XSQ) & 0,456 & 15 & 0,634 & 16 & 1 & 0,6145 & 0,4577 & 0,9298 & 0,5329 \\
\hline BURBERRY GROUP & 0,434 & 16 & 0,651 & 15 & -1 & 0,5486 & 0,5798 & 0,7409 & 0,7361 \\
\hline MRPRICEGROUP & 0,411 & 17 & 0,612 & 17 & 0 & 0,8859 & 0,1704 & 0,8471 & 0,5459 \\
\hline CHRISTIANDIOR & 0,406 & 18 & 0,600 & 18 & 0 & 0,3642 & 0,8351 & 0,8659 & 0,3358 \\
\hline WACOALHDG. & 0,391 & 19 & 0,542 & 21 & 2 & 0,8211 & 0,7323 & 0,5102 & 0,106 \\
\hline FASTRETAILING & 0,390 & 20 & 0,532 & 22 & 2 & 0,6224 & 0,6359 & 0,7642 & 0,1041 \\
\hline$(\ldots)$ & $(\ldots)$ & $(\ldots)$ & $(\ldots)$ & $(\ldots)$ & $(\ldots)$ & $(\ldots)$ & $(\ldots)$ & $(\ldots)$ & $(\ldots)$ \\
\hline OROTONGROUP & 0,193 & 40 & 0,237 & 39 & -1 & 0,359 & 0,1421 & 0,2065 & 0,24 \\
\hline GIORDANOINTL & 0,185 & 41 & 0,276 & 37 & -4 & 0,1102 & 0,2371 & 0,4262 & 0,3322 \\
\hline URBANOUTFITTERS & 0,170 & 42 & 0,233 & 40 & -2 & 0,1636 & 0,1074 & 0,1623 & 0,4969 \\
\hline $\begin{array}{l}\text { RUENTEX } \\
\text { INDUSTRIES }\end{array}$ & 0,159 & 43 & 0,153 & 43 & 0 & 0,4453 & 0,0981 & 0,0535 & 0,0168 \\
\hline $\begin{array}{l}\text { CHINADONGXIANG } \\
\text { (GROUP) }\end{array}$ & 0,158 & 44 & 0,120 & 46 & 2 & 0,0211 & 0,1335 & 0,1078 & 0,217 \\
\hline GUNZE & 0,148 & 45 & 0,127 & 45 & 0 & 0,1074 & 0,288 & 0,094 & 0,0204 \\
\hline ONWARDHOLDINGS & 0,148 & 46 & 0,153 & 44 & -2 & 0,1318 & 0,3581 & 0,0944 & 0,0267 \\
\hline PORTSDESIGN & 0,144 & 47 & 0,117 & 47 & 0 & 0,0788 & 0,1109 & 0,1278 & 0,1486 \\
\hline AOYAMATRADING & 0,119 & 48 & 0,108 & 49 & 1 & 0,1715 & 0,2008 & 0,0409 & 0,0207 \\
\hline $\begin{array}{l}\text { BOSIDENG } \\
\text { INTLHOLDINGS } \\
\end{array}$ & 0,119 & 49 & 0,112 & 48 & -1 & 0,1271 & 0,131 & 0,0787 & 0,1099 \\
\hline ECLATTEXTILE & 0,119 & 50 & 0,071 & 50 & 0 & 0,0648 & 0,1514 & 0,0472 & 0,0191 \\
\hline SHIMAMURA & 0,119 & 51 & 0,049 & 52 & 1 & 0,0501 & 0,0876 & 0,0377 & 0,019 \\
\hline
\end{tabular}


Preprint: Escrig-Olmedo, E., Rivera-Lirio, J. M., Muñoz-Torres, M. J., \& Fernández-Izquierdo, M. Á. (2017). Integrating multiple ESG investors' preferences into sustainable investment: A fuzzy multicriteria methodological approach. Journal of Cleaner Production, 162, 1334-1345.

\begin{tabular}{|l|r|r|r|r|r|r|r|r|r|}
\hline TAINANSPINNING & 0,119 & 52 & 0,053 & 51 & -1 & 0,0584 & 0,0981 & 0,0403 & 0,0161 \\
\hline
\end{tabular}

Scenario 2

\begin{tabular}{|c|c|c|c|c|c|c|c|c|c|}
\hline COMPANY & $\begin{array}{l}\text { FUZZY } \\
\text { TOPSIS } \\
\text { SCORE }\end{array}$ & $\begin{array}{l}\text { FUZZY } \\
\text { TOPSIS } \\
\text { RANK } \\
\text { (I) } \\
\end{array}$ & $\begin{array}{l}\text { ASSET4 } \\
\text { SCORE }\end{array}$ & $\begin{array}{c}\text { ASSET4 } \\
\text { RANK } \\
\text { (II) }\end{array}$ & $\begin{array}{c}\text { DIF } \\
\text { (II-I) }\end{array}$ & $\begin{array}{c}\text { ECO } \\
\text { ASSET4 } \\
\text { SCORE }\end{array}$ & $\begin{array}{c}\text { ENV } \\
\text { ASSET4 } \\
\text { SCORE }\end{array}$ & $\begin{array}{c}\text { SOC } \\
\text { ASSET4 } \\
\text { SCORE }\end{array}$ & $\begin{array}{c}\text { GOV } \\
\text { ASSET4 } \\
\text { SCORE }\end{array}$ \\
\hline $\mathrm{PVH}$ & 0.634 & 1 & 0.919 & 1 & 0 & 0,8976 & 0,882 & 0,9664 & 0,93 \\
\hline $\begin{array}{ll}\text { MARKS } & \& \\
\text { SPENCER 'B' }\end{array}$ & 0.614 & 2 & 0.846 & 3 & 1 & 0,615 & 0,916 & 0,931 & 0,9231 \\
\hline $\begin{array}{l}\text { GILDAN } \\
\text { ACTIVEWEAR }\end{array}$ & 0.609 & 3 & 0.868 & 2 & -1 & 0,6985 & 0,9037 & 0,9415 & 0,9294 \\
\hline NEXT & 0.582 & 4 & 0.779 & 8 & 4 & 0,5059 & 0,88 & 0,8738 & 0,8566 \\
\hline $\begin{array}{ll}\text { DAVID } & \text { JONES } \\
\text { DEFERRED } & \\
\end{array}$ & 0.577 & 5 & 0.818 & 5 & 0 & 0,886 & 0,722 & 0,7817 & 0,8837 \\
\hline INDITEX & 0.574 & 6 & 0.758 & 9 & 3 & 0,5629 & 0,8508 & 0,9245 & 0,6938 \\
\hline GAP & 0.565 & 7 & 0.834 & 4 & -3 & 0,9691 & 0,7049 & 0,7165 & 0,9441 \\
\hline NORDSTROM & 0.563 & 8 & 0.792 & 6 & -2 & 0,6915 & 0,8421 & 0,8332 & 0,8021 \\
\hline $\begin{array}{l}\text { RICHEMONT SECS. } \\
\text { (BER) }\end{array}$ & 0.551 & 9 & 0.789 & 7 & -2 & 0,9777 & 0,8274 & 0,9105 & 0,441 \\
\hline $\begin{array}{ll}\text { LOUIS } & \text { VUITTON } \\
\text { (EAS) } & \end{array}$ & 0.536 & 10 & 0.702 & 12 & 2 & 0,6172 & 0,9078 & 0,9133 & 0,3695 \\
\hline $\begin{array}{l}\text { TRUWORTHS } \\
\text { INTL. }\end{array}$ & 0.505 & 11 & 0.697 & 13 & 2 & 0,7843 & 0,3995 & 0,9071 & 0,6988 \\
\hline L BRANDS & 0.500 & 12 & 0.655 & 14 & 2 & 0,6058 & 0,562 & 0,7205 & 0,7301 \\
\hline VF & 0.487 & 13 & 0.727 & 10 & -3 & 0,7046 & 0,8392 & 0,5556 & 0,8083 \\
\hline CHRISTIAN DIOR & 0.485 & 14 & 0.600 & 18 & 4 & 0,3642 & 0,8351 & 0,8659 & 0,3358 \\
\hline FOSCHINI (XSQ) & 0.484 & 15 & 0.634 & 16 & 1 & 0,6145 & 0,4577 & 0,9298 & 0,5329 \\
\hline $\begin{array}{ll}\text { HENNES } & \& \\
\text { MAURITZ'B' } & \end{array}$ & 0.477 & 16 & 0.583 & 19 & 3 & 0,3532 & 0,8959 & 0,6764 & 0,4047 \\
\hline $\begin{array}{l}\text { BURBERRY } \\
\text { GROUP }\end{array}$ & 0.462 & 17 & 0.651 & 15 & -2 & 0,5486 & 0,5798 & 0,7409 & 0,7361 \\
\hline PACIFIC BRANDS & 0.453 & 18 & 0.722 & 11 & -7 & 0,7592 & 0,7958 & 0,5871 & 0,7451 \\
\hline ESPRIT HOLDINGS & 0.427 & 19 & 0.549 & 20 & 1 & 0,1625 & 0,7466 & 0,714 & 0,5735 \\
\hline $\begin{array}{l}\text { AMER.EAG.OUTFIT } \\
\text { TERS }\end{array}$ & 0.413 & 20 & 0.524 & 23 & 3 & 0,3441 & 0,4505 & 0,5006 & 0,8004 \\
\hline$(\ldots)$ & $(\ldots)$ & $(\ldots)$ & $(\ldots)$ & $(\ldots)$ & $(\ldots)$ & $(\ldots)$ & $(\ldots)$ & $(\ldots)$ & $(\ldots)$ \\
\hline $\begin{array}{l}\text { URBAN } \\
\text { OUTFITTERS }\end{array}$ & 0.196 & 39 & 0.233 & 40 & 1 & 0,1636 & 0,1074 & 0,1623 & 0,4969 \\
\hline SUPERGROUP & 0.195 & 40 & 0.249 & 38 & -2 & 0,1793 & 0,18 & 0,1599 & 0,4767 \\
\hline OROTONGROUP & 0.184 & 41 & 0.237 & 39 & -2 & 0,359 & 0,1421 & 0,2065 & 0,24 \\
\hline GUNZE & 0.183 & 42 & 0.127 & 45 & 3 & 0,1074 & 0,288 & 0,094 & 0,0204 \\
\hline $\begin{array}{l}\text { ONWARD } \\
\text { HOLDINGS }\end{array}$ & 0.183 & 43 & 0.153 & 44 & 1 & 0,1318 & 0,3581 & 0,0944 & 0,0267 \\
\hline GIORDANO INTL. & 0.176 & 44 & 0.276 & 37 & -7 & 0,1102 & 0,2371 & 0,4262 & 0,3322 \\
\hline $\begin{array}{l}\text { RUENTEX } \\
\text { INDUSTRIES }\end{array}$ & 0.175 & 45 & 0.153 & 43 & -2 & 0,4453 & 0,0981 & 0,0535 & 0,0168 \\
\hline $\begin{array}{l}\text { CHINA } \\
\text { DONGXIANG } \\
\text { (GROUP) } \\
\end{array}$ & 0.154 & 46 & 0.120 & 46 & 0 & 0,0211 & 0,1335 & 0,1078 & 0,217 \\
\hline $\begin{array}{l}\text { BOSIDENG } \\
\text { INTL.HOLDINGS }\end{array}$ & 0.152 & 47 & 0.112 & 48 & 1 & 0,1271 & 0,131 & 0,0787 & 0,1099 \\
\hline PORTS DESIGN & 0.143 & 48 & 0.117 & 47 & -1 & 0,0788 & 0,1109 & 0,1278 & 0,1486 \\
\hline $\begin{array}{l}\text { AOYAMA } \\
\text { TRADING } \\
\end{array}$ & 0.142 & 49 & 0.108 & 49 & 0 & 0,1715 & 0,2008 & 0,0409 & 0,0207 \\
\hline ECLAT TEXTILE & 0.122 & 50 & 0.071 & 50 & 0 & 0,0648 & 0,1514 & 0,0472 & 0,0191 \\
\hline
\end{tabular}


Preprint: Escrig-Olmedo, E., Rivera-Lirio, J. M., Muñoz-Torres, M. J., \& Fernández-Izquierdo, M. Á. (2017). Integrating multiple ESG investors' preferences into sustainable investment: A fuzzy multicriteria methodological approach. Journal of Cleaner Production, 162, 1334-1345.

\begin{tabular}{|l|r|r|r|r|r|r|r|r|r|}
\hline SHIMAMURA & 0.122 & 51 & 0.049 & 52 & 1 & 0,0501 & 0,0876 & 0,0377 & 0,019 \\
\hline TAINAN SPINNING & 0.122 & 52 & 0.053 & 51 & -1 & 0,0584 & 0,0981 & 0,0403 & 0,0161 \\
\hline
\end{tabular}


Preprint: Escrig-Olmedo, E., Rivera-Lirio, J. M., Muñoz-Torres, M. J., \& Fernández-Izquierdo, M. Á. (2017). Integrating multiple ESG investors' preferences into sustainable investment: A fuzzy multicriteria methodological approach. Journal of Cleaner Production, 162, 1334-1345.

Figure 1. Integration of ESG criteria and investors' preferences. An Outline

\section{ESG CRITERIA INTEGRATION}

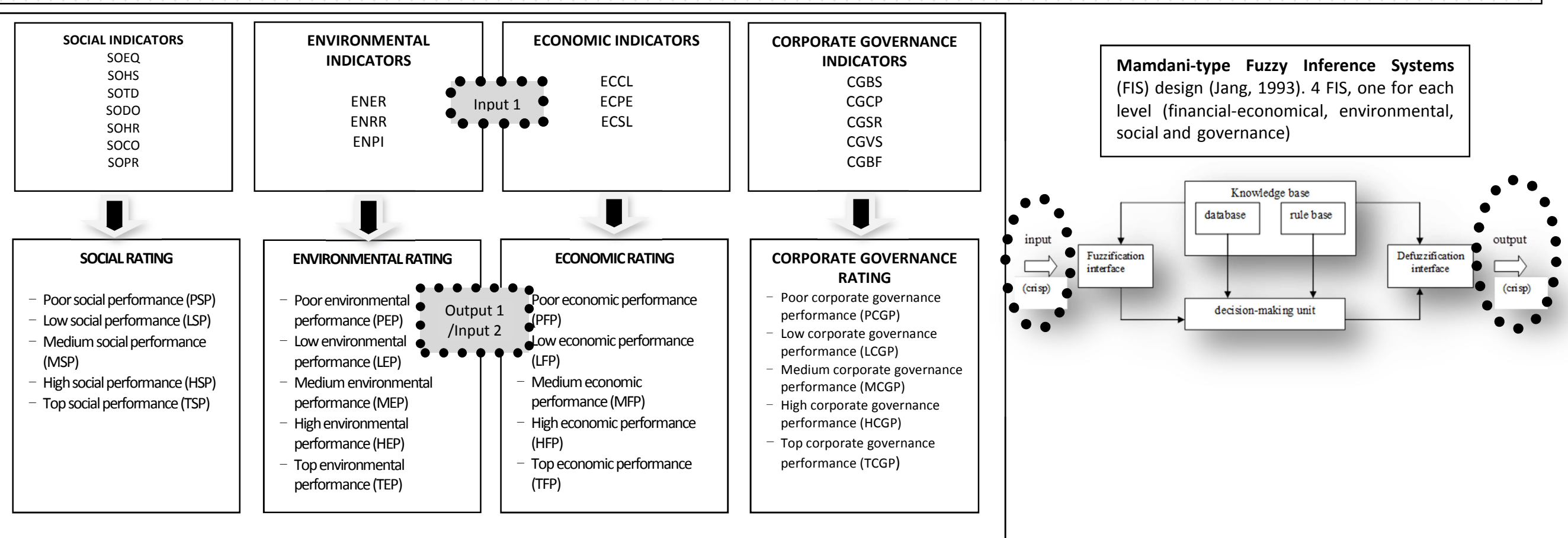

\section{INTEGRATION OF INVESTORS' PREFERENCES}

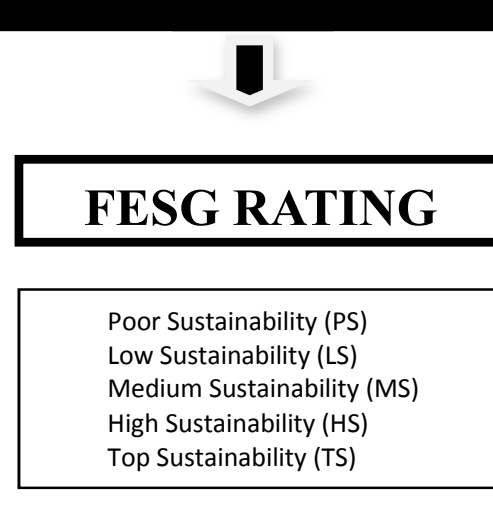

Output 2
Fuzzy TOPSIS model design with a specific set of rules and variables in order to incorporate the main three external DMs' preferences of wearing apparel sector.
Relative importance weights for domain

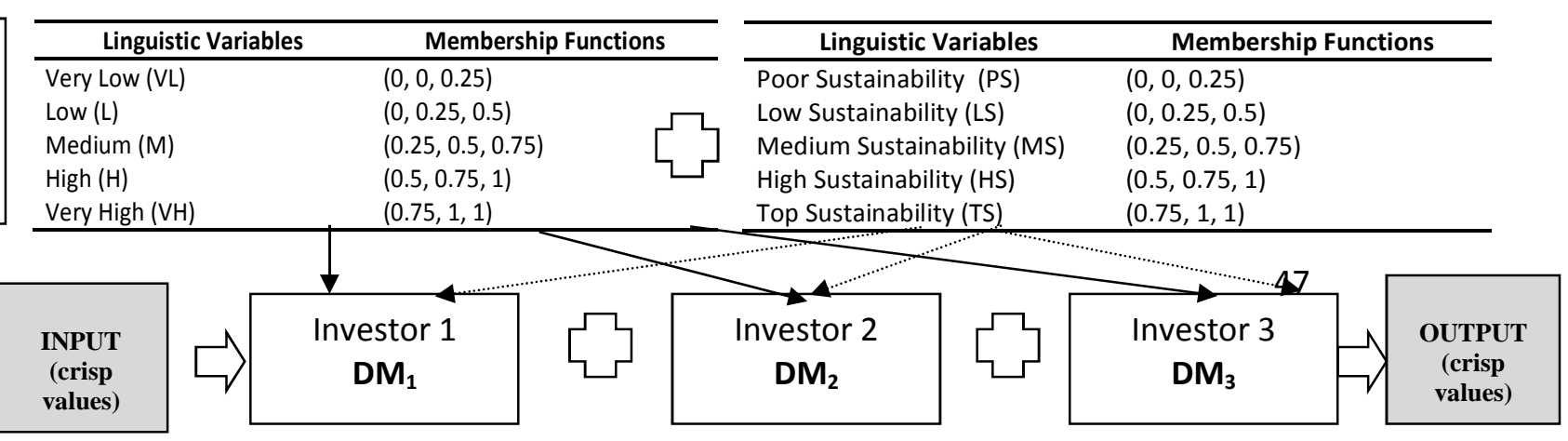


Preprint: Escrig-Olmedo, E., Rivera-Lirio, J. M., Muñoz-Torres, M. J., \& Fernández-Izquierdo, M. Á. (2017). Integrating multiple ESG investors' preferences into sustainable investment: A fuzzy multicriteria methodological approach. Journal of Cleaner Production, 162, 1334-1345.

Figure 2. Correlation among individual investors rankings vs. fuzzy TOPSIS rankings per scenario Scenario 1
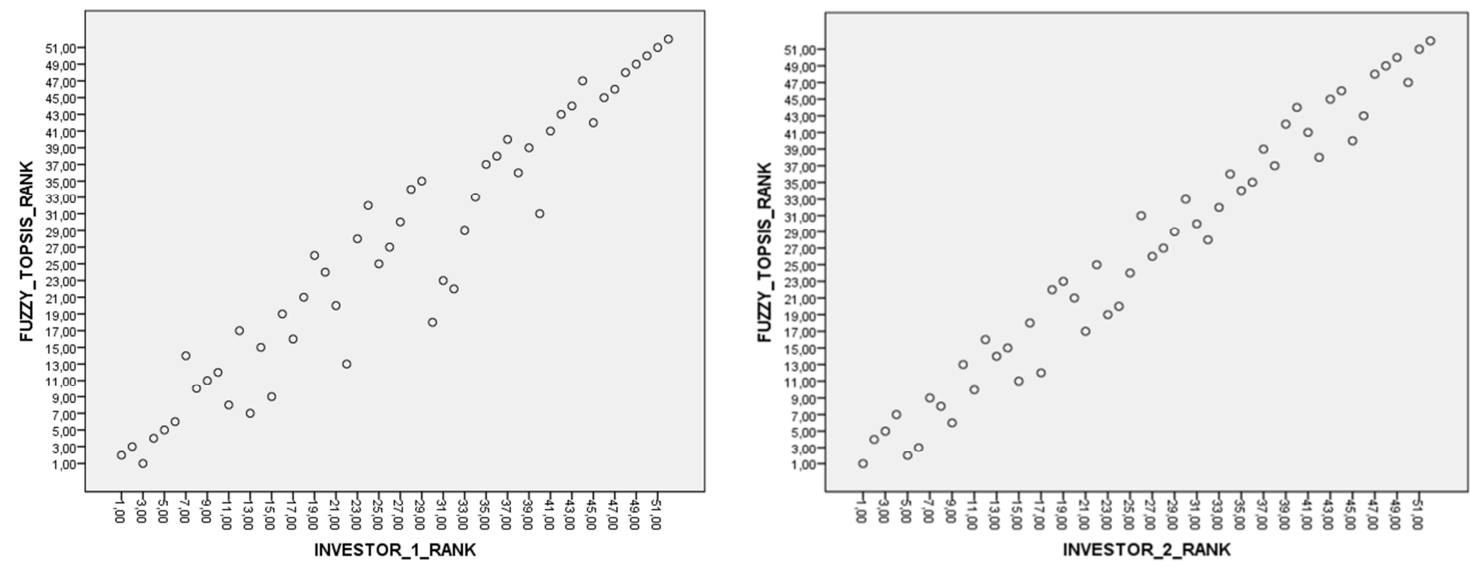

\begin{tabular}{|l|l|l|}
\cline { 2 - 3 } \multicolumn{1}{c|}{} & \multicolumn{2}{c|}{$\begin{array}{c}\text { Spearman's rank } \\
\text { correlation between } \\
\text { rankings }\end{array}$} \\
\cline { 2 - 3 } \multicolumn{1}{c|}{} & $\begin{array}{c}\text { FUZZY_- } \\
\text { TOPSIS } \\
\text { RANK }\end{array}$ & $\begin{array}{c}\text { ASSET4 } \\
\text { RANK }\end{array}$ \\
\hline INVESTOR_1_RANK &, $959 * *$ &, $942 * *$ \\
\hline INVESTOR_2_RANK &, $984 * *$ &, $985 * *$ \\
\hline INVESTOR_3_RANK &, $994 * *$ &, $986 * *$ \\
\hline$* *$ Correlation is significant at the 0.01 level (2-tailed) \\
\hline
\end{tabular}

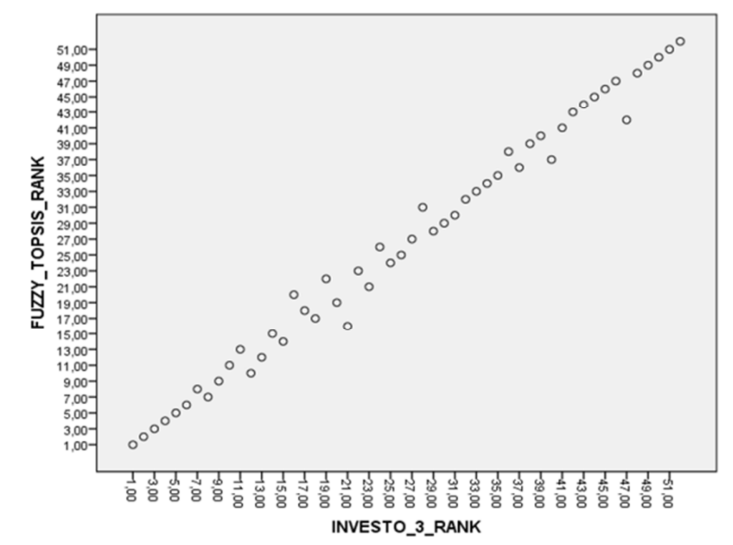


Preprint: Escrig-Olmedo, E., Rivera-Lirio, J. M., Muñoz-Torres, M. J., \& Fernández-Izquierdo, M. Á. (2017). Integrating multiple ESG investors' preferences into sustainable investment: A fuzzy multicriteria methodological approach. Journal of Cleaner Production, 162, 1334-1345.

Scenario 2
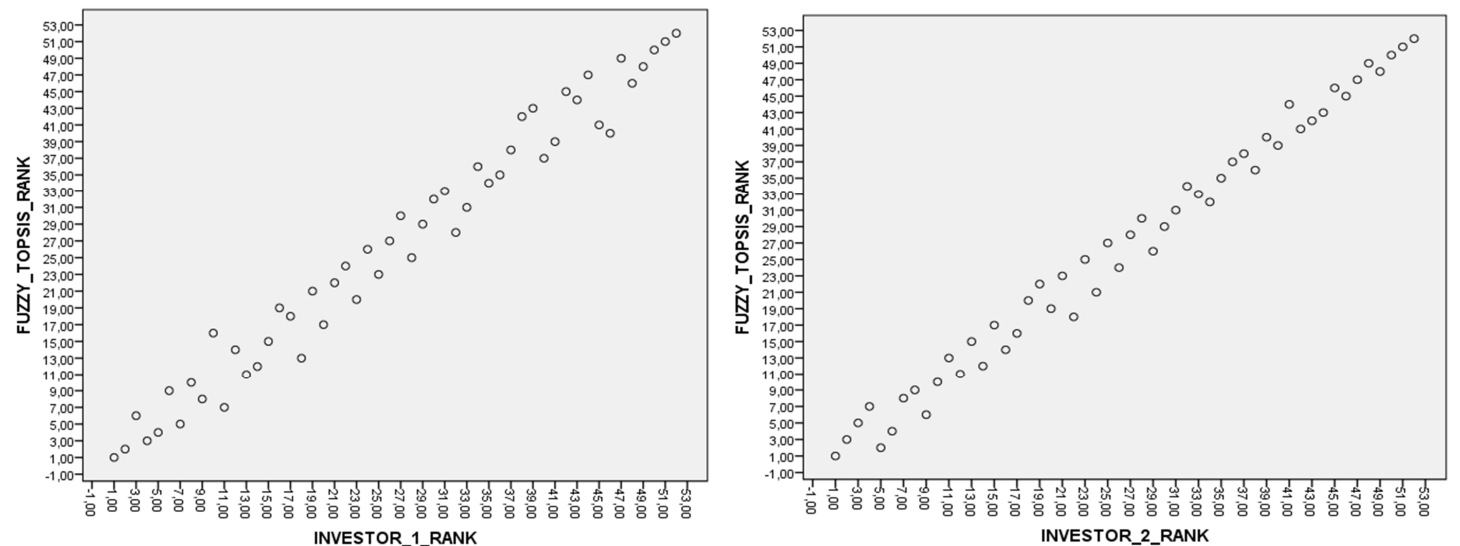

\begin{tabular}{|l|l|l|}
\cline { 2 - 3 } \multicolumn{1}{c|}{} & \multicolumn{2}{c|}{$\begin{array}{c}\text { Spearman's rank } \\
\text { correlation between } \\
\text { rankings }\end{array}$} \\
\cline { 2 - 3 } \multicolumn{1}{c|}{} & $\begin{array}{c}\text { FUZZY_- } \\
\text { TOPSIS } \\
\text { RANK }\end{array}$ & $\begin{array}{c}\text { ASSET4 } \\
\text { RANK }\end{array}$ \\
\hline INVESTOR_1_RANK &, $985^{* *}$ &, $968^{* *}$ \\
\hline INVESTOR_2_RANK &, $993^{* *}$ &, $984^{* *}$ \\
\hline INVESTOR_3_RANK &, $995^{* *}$ &, $980^{* *}$ \\
\hline ** Correlation is significant at the 0.01 level (2-tailed) \\
\hline
\end{tabular}

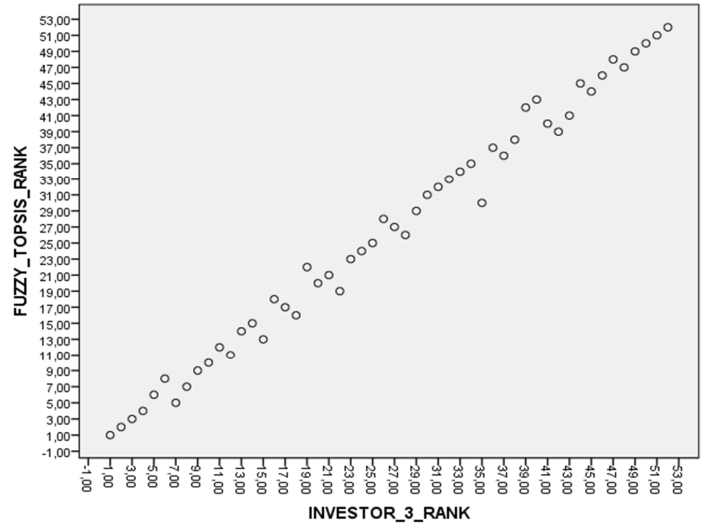

